\title{
The periphery of Lepcis Magna: new data related to the ancient road network and land partition
}

\author{
By Andrea Zocchi"
}

\begin{abstract}
This contribution offers a new reading of the ancient landscape of the periphery of Lepcis Magna thanks mainly to the data from the survey campaigns carried out by the Archaeological Mission of Roma Tre University (200713) together with new archival research and GIS analysis. The new data are related to the road network of the Lepcitanian territory and its inner suburban areas. They include both the already known routes (essentially the coastal via publica and the via in mediterraneum) and new roads here presented merging the new information with the already published archaeological evidence. Beside the road network, a new topographic reading of the south-east suburb shows also traces of an ancient land partition based on Roman measurements. This latter discovery would represent, up to now, the first evidence of a cadastrian land partition in Tripolitania.
\end{abstract}

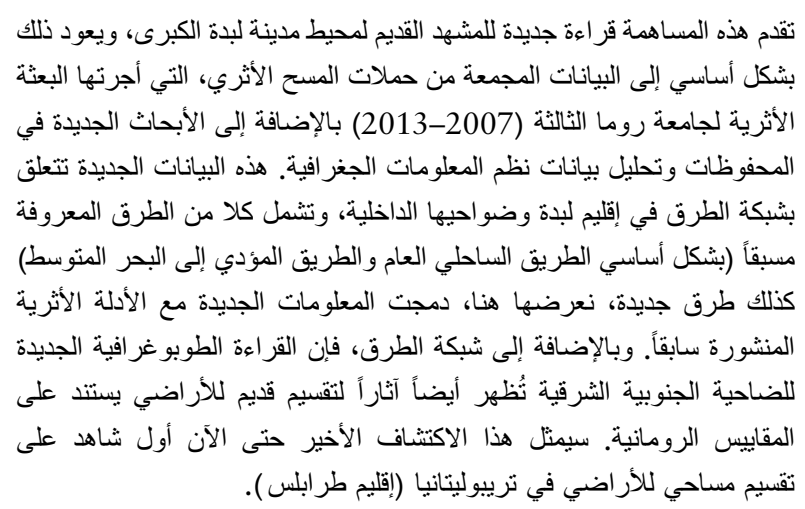

\section{Introduction: ancient roads and tracks in Tripolitania}

Knowledge of the Roman road network in Africa rests mainly, on the one hand, on the finding of milestones and, on the other, on the analysis of ancient Itineraria. Both of these help us to trace the routes though uncertainties remain, since their courses were characterised essentially by beaten earth and thus hardly recognisable on the ground (general accounts in Desanges et al. 2010, 39-47; Romanelli 1970, 8-23; Salama 1951a). In addition to the Itineraria and milestones, the analysis of maps, satellite images and aerial photographs can help identify

\footnotetext{
* University of Leicester; Roma Tre University Archaeological Mission in Libya.
}

modern tracks that may have been used in ancient time. However, this can be problematic since sometimes it is hard to distinguish between antique routes and ones used exclusively in later periods, especially where the lack of close archaeological evidence makes it difficult to read the ancient landscape properly.

The current knowledge of the Tripolitanian ancient road network is based on the three factors mentioned above. The general frame of the regional routes was first established by Richard Goodchild (1948) and, apart from some corrections due to new findings that have occurred in the last 70 years, his overview remains valid. Three main roads have been identified within the region (Figure 1; see also Desanges et al. 2010, pl. 5; Talbert 2000, pl. 35): the sector of the route that followed the entire African coast from Mauretania to Aegyptus, an internal road that passed through the Gebel from Tacape (Gabes) to Lepcis Magna and a route that from Oea headed southwards reaching the Roman fort of Mizda. Other connections linked up with these three main routes: the internal Lepcis Magna road; Oea via Mesphe (Medina Doga); and the one between the forts of Mizda and Thenteos (Zintan). Of course, many other caravan tracks and roads no longer traceable must have linked the minor settlements and the different forts, centenaria or outposts of the limes reaching also the furthest Roman forts of Cidamus, Gheriat el-Garbia and Bu Njem.

Apart from the roads that linked Midza to Oea and to Thenteos, the other routes mentioned above are included in both the Peutinger Table - a medieval copy of an itinerarium pictum dated to the late second century AD - and the Antonine Itinerary a list of sites and distances dated to the early third century AD (Chevallier 1989, 28-37; Cuntz 1929; Desanges et al. 2010, 17, 69-71, 73-76; Miller 1916). Every route in the two Itineraria mentions the main sites with distances and this fundamental information helps to locate and identify many other different categories of settlements/structures thanks to their toponyms (Mattingly 1995, 61-62). In addition to these two ancient sources, there are also the site lists included in the Ravennatis Anonymi Cosmographia dated to the seventh century AD and in the Liber Guidonis, in which, however, the 


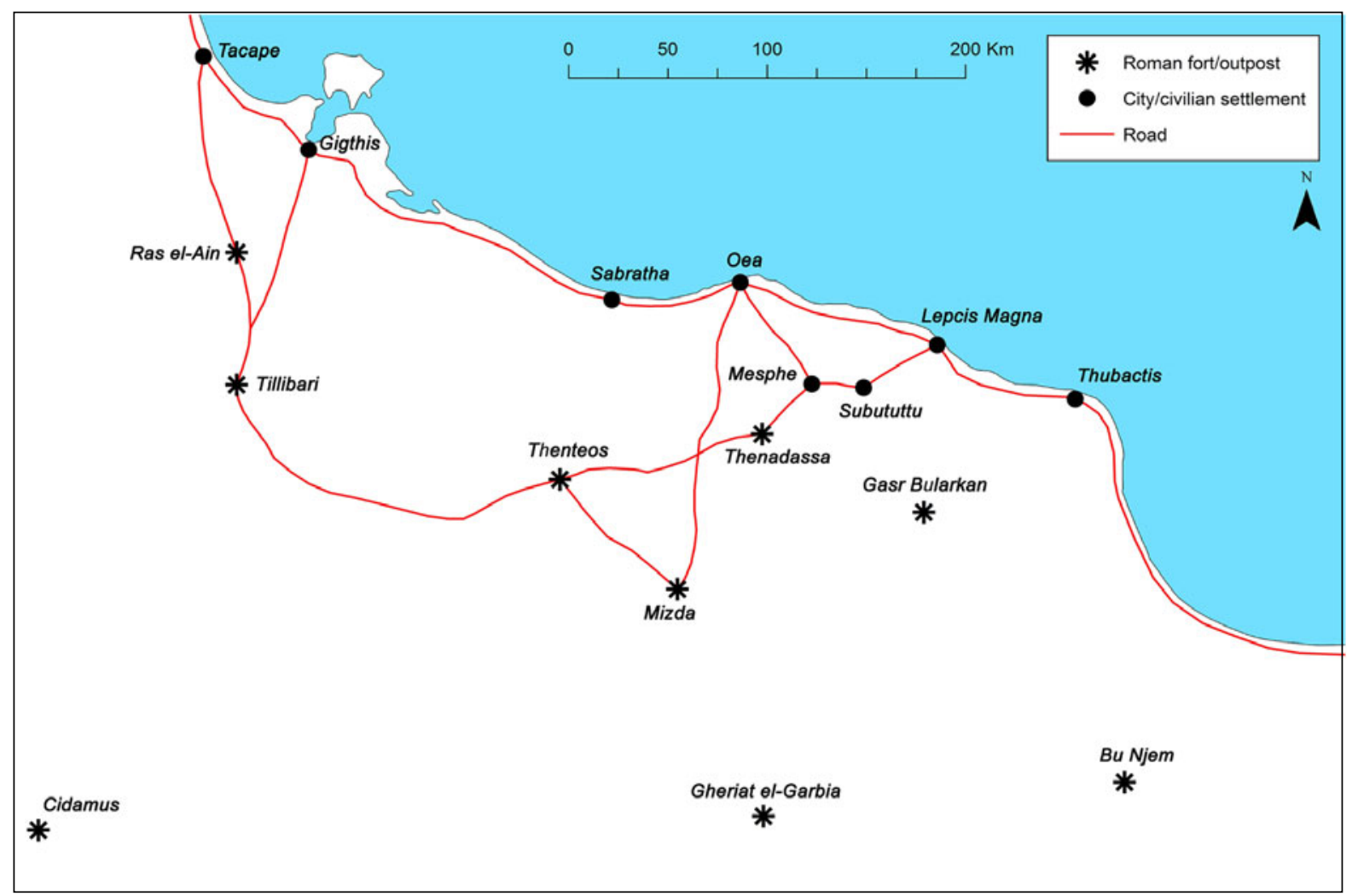

Figure 1. The ancient road network of Tripolitania (third century AD).

distances between places are not provided (Chevallier 1989, 38-39; Desanges et al. 2010, 18, 77-80).

The coastal road in Tripolitania linked Tacape (Gabes) to Thubactis (probably Misurata Marina: Desanges et al. 2010, 255-56) and put in direct connection the three main port cities of the region: Sabratha, Oea and Lepcis Magna (for the western sector of Sabratha, see Munzi and Zennati 2004). This important route was in use, almost certainly in many sectors, before the Romans took control of the region and the milestones found along its path are dated from Augustus to the late third century (Di Vita-Evrard 1978-79). It was also used, in some sectors and with variations, until the medieval Arab pilgrimages to the holy cities in the Middle East. However, its exact course cannot always be identified with certainty because it seems to have followed a more inland route in places, probably to avoid wadis and areas characterised by sand dunes (Desanges et al. 2010, 47; Goodchild 1948, 9-10; 1968, 158; Mattingly 1995, 61-62; Merighi 1940, II, 191-99).

The main inland road that ran in a wide arc ran from Tacape to Lepcis Magna connecting the main Roman forts along the Gebel, is indicated in the Antonine Itinerary as 'Iter quod limitem
Tripolitanum per Turrem Tamalleni a Tacapis Lepti Magna ducit'. Indeed this route should have had a significant military and economic role since it linked the forts of Ras el-Aïn, Tillibari (Remada), Thenteos, Thenedassa (Aïn Wif) and then reached the rich agricultural areas of the settlements of Mesphe and Subututtu (Gasr ed-Daun) to the east. The eastern sector was surely in use at least from the beginning of the first century $\mathrm{AD}$ when the terminal milestone (IRT 930) was set outside the city of Lepcis Magna by the proconsul L. Aelius Lamia (AD 15-17), who built the road for 44 miles into the interior, probably the terminus of the Lepcitanian territory towards the south-west (see Part 2.4). The route was certainly in use until the Late Antique period and the milestones found along its path date from Caracalla to Gallienus (Di Vita-Evrard 1979, 90; Goodchild 1948, 11; 1951, 75-76; 1968, 158-59; Mattingly 1995, 62-66; Oates 1953, 89-92; Romanelli 1970, 13).

The milestones that have been found along the Tripolitanian roads can be dated mainly to the third century $\mathrm{AD}(87 \%$ of the total) and especially to the reign of Caracalla. In this region, as other Roman provinces, late milestones were used not only to remember restorations or works made on the routes but they often acted as a political 
propaganda tool (Mattingly 1995, 61; Salama 1951b; 1987). Moreover, the reorganisation of the limes started by Septimius Severus, and continued by the Severan dynasty, certainly played a fundamental role in redefining, and then marking, the main routes that reached the limes from the coast as well as those that crossed it.

Caracalla's milestones (and, in general, thirdcentury ones) seem to have had common features in Tripolitania. The inscription is almost always carved on a limestone column with a shaft of approximately $2.20 \mathrm{~m}$ high and a diameter of c. $40-50 \mathrm{~cm}$. Unlike the majority of the milestones of Cyrenaica and elsewhere in the Roman Empire, the column shaft was here separated from the base. This latter element was essentially a limestone cube/parallelepiped with a circular recess to house the column (Goodchild 1948, 7; 1968, 156; Romanelli 1970, 12). This is an important detail, since in the post-Antique period the milestone columns were frequently reused as architectural elements in new buildings while their bases were often left in situ, thus leaving for us a clear indication of the road route (see Kolb 2011 for a general account of milestones' shapes, characteristics and reuse).

\section{The peripheral road network of Lepcis Magna: the main routes}

According to the Peutinger Table and to the Antonine Itinerary, two main roads reached Lepcis Magna in Roman time: the coastal road and the so-called via in mediterraneum also known as the 'East Gebel road'. The epigraphic evidence of milestones helps to both define, more or less, the routes of these two roads in the close Lepcitanian territory and confirm what is indicated in the two Itineraria.

New data from recent surveys ${ }^{1}$ and from the analysis of cartographies and aerial/satellite images also allow us to hypothesise the existence of two other major routes that led inland (Figure 2). The remains of a milestone base together with aerial photo interpretation would indicate the existence of a road that ran southwards from Lepcis Magna towards the Orfella region (Beni Ulid) and the south and east sector of the limes (see Part 2.5). Another important road seems to have linked the city to the area of Ras el-Mergheb to the west and, from there, probably rejoined the coastal road (see Part 2.3).

\subsection{The coastal road (north-western sector)}

West of Lepcis Magna the coastal road can be traced above all by the presence of seven milestones that, even if almost always not found in situ, would more or less suggest its route. This archaeological evidence is related to the restoration works that occurred in the third century $\mathrm{AD}$ all across Tripolitania; however, it is highly presumable that in the previous centuries the road followed - perhaps with minor variations - the same path.

From the Severan arch, the decumanus maximus (the coastal road within the city) ran on a consistent sector north-west passing through the Antoninus Pius arch (the west gate from the fourth century $\mathrm{AD}$ ) and the Marcus Aurelius arch (Figure 3). The road sector between these last two arches was fully urbanised and defined, at least from the mid-Imperial Roman period, by continuous colonnaded porticoes on both sides. In this sector the road is still paved with limestone slabs and is $5.50 \mathrm{~m}$ wide, enough to allow the transit of two vehicles. After the Marcus Aurelius arch the road turned slightly towards the west, aiming for a point c. $600 \mathrm{~m}$ south of Cape Hermaion (Khoms). In this sector, both the position and orientation of the route are certain: part of the road was dug near the west bank of Wadi er-Rsaf (Figure 3.A) and the first milestone was found close to the west bank of Wadi Zennad (Figures 2.A; 3.B). Moreover, the presence of several mausolea (Figure 3.C-G), hypogean tombs (Figure 3.H-J) and necropoleis (Figure 3.K-M) flanking the supposed route would confirm the exact location of its passage. During the 1990s, Roma Tre University explored part of the Wadi er-Rsaf area bringing to light a section of the road that in this part was unpaved and wide, during the second/third century AD, c. $11.5 \mathrm{~m}$ (Musso et al. 1997, 286-87; 1998, 207-9). The excavation revealed the presence of a compact sandy surface dented by numerous wheel ruts sometimes filled and levelled together with several hollows from the late second century $\mathrm{AD}$ onwards. ${ }^{2}$ Beneath this layer, other compact clayish surfaces of the route were found while the lowest strata dug (dated to the first century $\mathrm{AD}$ ) indicate the presence of a structure in the northern sector of the trench, probably a narrower version of the road or a different route. However, in the mid-Imperial Roman period the road was in this sector more than $11.5 \mathrm{~m}$ wide, that is similar to the value reported by Hyginus Gromaticus (De limitus constituendis 194. 9-16) who mentioned an Augustan disposition that imposed the width of the decumanus maximus in relation to the agri centuriati (thus outside the city) as equal to 40 feet (c. $11.8 \mathrm{~m})$. Moreover, the remarkable width of the road in this sector could be related to the presence of warehouses (Figure 3.N-O; Musso et al. 1998, 210-12; Romanelli 1925, 156) and probably a 


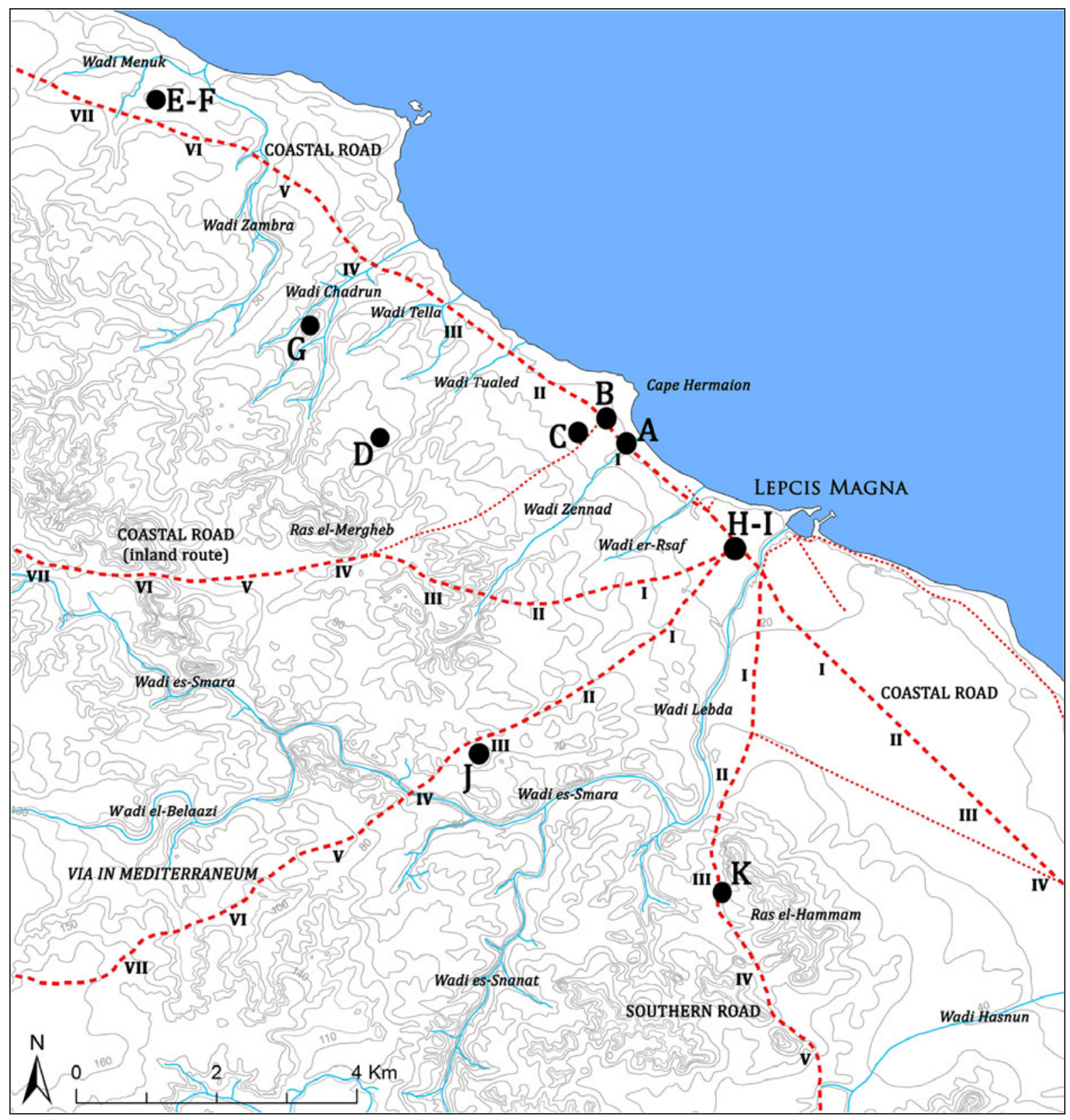

Figure 2. The Lepcis Magna peripheral road network with the milestone find-spots (letters A to K) and the numbering of miles according to the routes hypothesised.

caravanserai (Figure 3.P; Jones 1989, 96-99, Musso et al. 1996, 155-56, 165-66; Romanelli 1925, 156) and therefore a place where the passage or rest of packed animals and wheeled transport was frequent and intense (see also Part 3.4 and Figure 20).

The discovery of the milestone (IRT 924) marking the first mile (Figures 2.A; 3.B), dated to the reign of Maximinus (AD 237), at short distance from the west bank of Wadi Zennad provides an important update concerning the western extension of the city in the second/third century AD. According to Salvatore Aurigemma (1925a, 19), the milestone was probably in situ, and thanks to the topographic information given by the Italian superintendent - close to the public butcher's shop outside Khoms, at short distance from the seashore and from the west bank of Wadi Zennad - it is possible to locate with accuracy its find-spot. It is plausible to suggest that, in the first half of the third century $\mathrm{AD}$ and probably also before, the western caput viae of the coastal road was at the Marcus Aurelius arch (Figure 3$)$ located exactly one mile $(1,481.5 \mathrm{~m})$ from the find-spot of the Maximinus milestone. Another milestone (Figure 2.B) related to the first mile and dated to Caracalla (Bakir 1966-67, 249; Gasperini 1988, 159-64) was found reused in the 


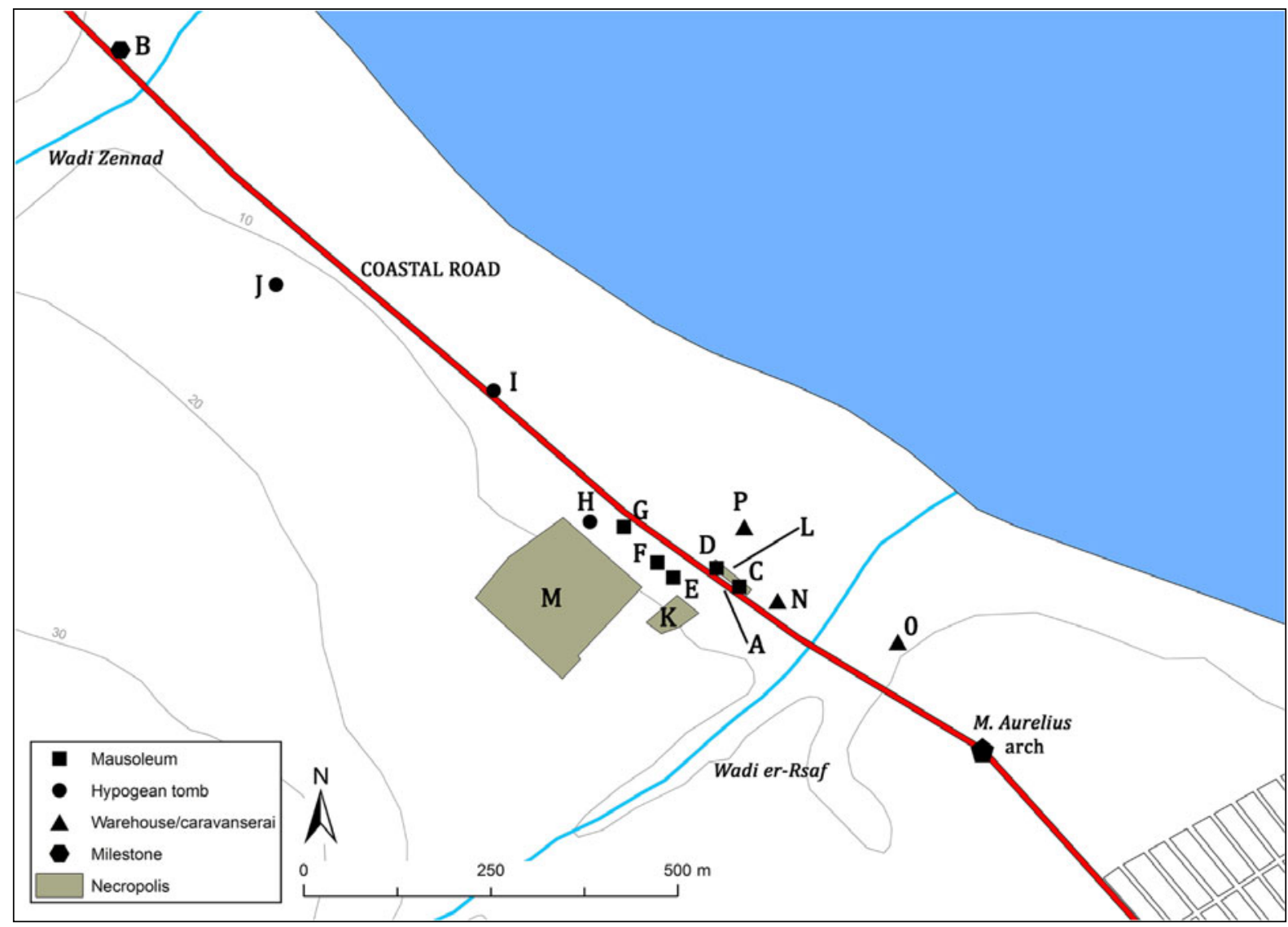

Figure 3. The first mile of the coastal road in the western suburbium.

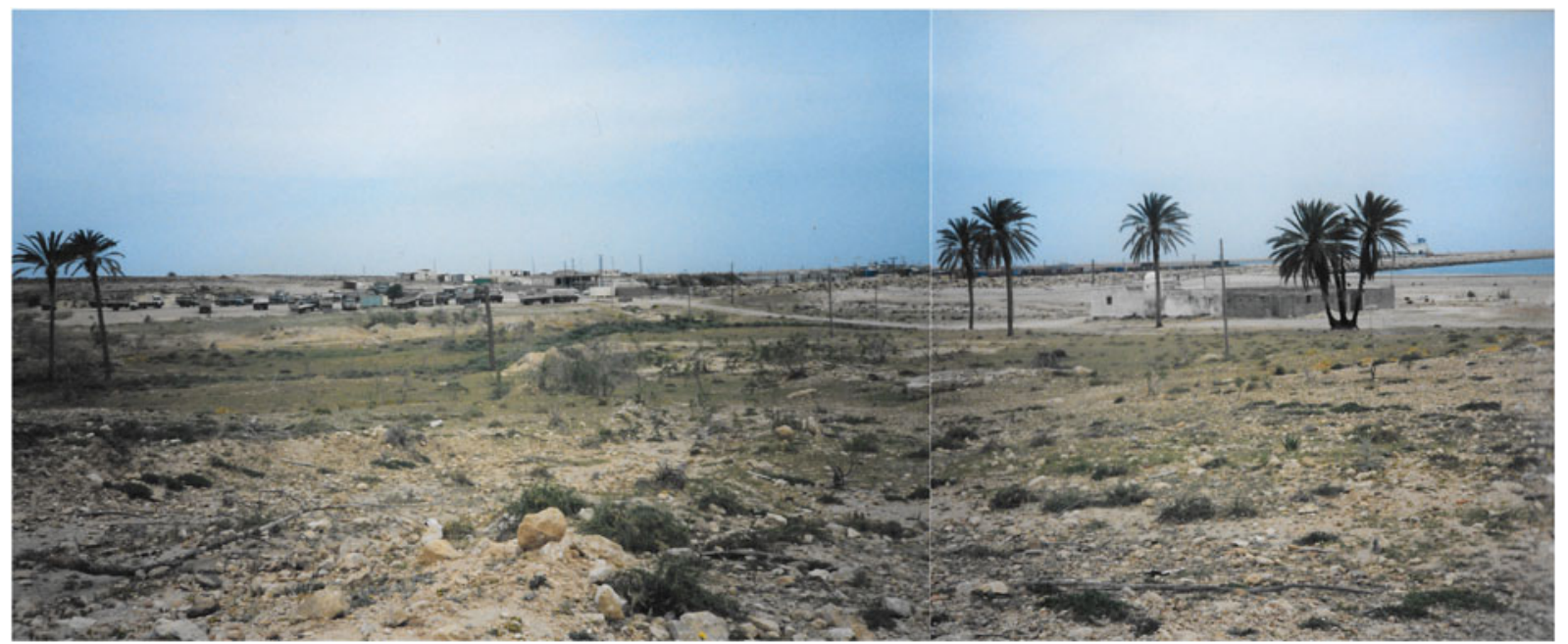

Figure 4. Sidi Abd Allah al Barrakish (on the right) shortly before its demolition due to the construction of the new harbour of Khoms. (Photo: L. Marsico, 1999)

'Turkish building' at Khoms (c. $450 \mathrm{~m}$ north-west from the Wadi Zennad milestone) where several archaeological finds were collected after its construction, in the mid-nineteenth century (Lothringen 1874, 167). However, the role of monumental arches used as the capita viarum should be significant due to their strong symbolic meaning and, like city gates, they could act as a passage from the proper urban area to a suburban district or separate two jurisdictional zones. In this sense, one of the best 
examples is the Ianus Augusti arch that marked the boundary between Hispania Tarraconensis and Baetica in the Guadalquivir valley and that was used as caput viae for the via Augusta (Holland 1961; Laing 1908, 28-29).

The coastal road, once it crossed Wadi Zennad, continued towards the north-west reaching the area of Cape Hermaion (Figure 2) and almost certainly underlay the modern street south of the 'Turkish building' at Khoms where the remains of a mausoleum were found still in situ during the 1960s (Bakir 1966$67,249)$. The ancient road probably continued, retracing the town street named by the Italians 'via XX Settembre', one of the oldest of Khoms, and together with the road south of the 'Turkish building' formed the main axis around which the modern town has developed during the nineteenth century.

Once past the modern city of Khoms the road continued north-west crossing Wadi Tualed and Wadi Tella and probably at a short distance from the seashore (Figure 2). Evidence of Roman coastal villae in this sector and of mausolea near the mouth of Wadi Tella found during a recent unpublished survey ${ }^{3}$ would suggest the presence of the road just a few hundred metres from the sea. Moreover, the construction during the early modern era of the marabouts of Sidi Za'id al Garib and Sidi Abd Allah al Barrakish (Figure 4; Cesàro 1933, 47; IGM 1918a; Müller 1855, tab. XXI; SPLAJ $1979 \mathrm{a}-\mathrm{b})$ close to the hypothesised ancient route north-west of Khoms would support the existence of an ancient road in this area. Unfortunately, no milestones have been found in situ in this sector. However, part of a Caracallan column shaft that marked the third mile (Figure 2.C; IRT 971, text in Aurigemma 1925b, 145) was found reused in the Sidi Ben Geha mosque at Khoms while another milestone dated to the reign of Maximinus (Figure 2.D; IRT 925) was found scattered on the ground near the et-Tualed village. Even if there is no trace of the mile number, it is possible to believe that this milestone could mark either the third mile, as suggested by Aurigemma (1925a, 15), or the second mile, located not far away from the west limit of Khoms. It is also possible that this latter milestone belonged to the inland route of the coastal road passing c. $1.5 \mathrm{~km}$ to the south (see Part 2.3).

The archaeological evidence related to the next sector of the road (north-west of Wadi Tella) is less clear. The recent discovery of two milestones (Figure 2.E-F; Munzi et al. 2004, 27-28, 44-45, site 5) dated to the reign of Caracalla and reused in the Late Antique phase of a villa rustica located near the mouth of Wadi Zambra could suggest that the coastal road ran at a short distance from this site. One of the two milestones marks the fifth mile, more or less located a few hundred metres south-east of the right branch of Wadi Zambra. The other milestone probably marked the sixth mile (Munzi et al. 2004, 28) but, according to its find-spot, it could also mark the seventh mile. A third milestone (Figure 2.G; IRT 926) dated to the reign of Emperor Tacitus (AD 276) and marking the fifth mile, was found reused in a Late Antique gasr located close to Wadi Chadrun (Méhier de Mathuisieulx 1906, 78; Munzi et al. 2004, 56, site 49 ) and c. $2 \mathrm{~km}$ south from the suggested original position. However, the events that characterised its reuse are not very clear and the accurate location of its original find-spot is uncertain (Aurigemma 1925a, 7-10; Munzi et al. 2004, 28-29).

Considering the position of the Tacitus milestone (Figure 2.G) and the Maximinus one (Figure 2.D), it is also possible to hypothesise an inland road that, starting from the area of Cape Hermaion, ran to the west, continuing its route a short distance north from the find-spot of the Maximinus milestone. From there it could have headed north-west avoiding the wadis and finally rejoining the coastal road once past Wadi Zambra. The Tacitus milestone (Figure 2.G) marking the fifth mile, even if found reused within the Late Antique gasr mentioned above, would fit more or less with this hypothetical route in terms of distance from the Marcus Aurelius arch. According to Aurigemma, this ancient road was overlapped by an Arab track - still partially visible - that linked the area of Cape Hermaion (Khoms) to the village of el Tura (Aurigemma 1925a, 9; IGM 1918a; Munzi et al. 2004, 28-30).

In the absence of further data it is reasonable to presume that the coastal via publica from Wadi Chadrun until the right branch of Wadi Menuk (Wadi as Sawalim) continued on the same orientation used by the so-called modern 'Port Road'. The presence of old Arab religious structures along its sides such as the marabouts of Sidi Abu Saydah and Sidi Abd as Salam (SPLAJ 1979b) could emphasise, once again, this hypothesis.

Two other milestones were found west of the area investigated and they marked the tenth mile (Munzi et al. 2004, 28, 48-49, dated to Caracalla) and the thirteenth mile (Salza Prina Ricotti 1970$71,153)$. Both the milestones were reused in subsequent structures; however, their find-spots (the first one at Gasr Silin $2 \mathrm{~km}$ from the coast, the other close to the coastal villa known as 'Villa dell'Odeon Marittimo') should not be far from 
their original locations as suggested by the mile number carved on them. Taken together, the archaeological evidence supports the view that the sector of the coastal road from Lepcis Magna to the first statio to the west cited by the Itineraria and named ad Palmam (Miller 1916, 897; Talbert 2000, pl. 35 G2) ran pretty close to the coastline and that the statio was located somewhere halfway between Wadi Jabrun and Wadi Ganima. It is important to note that the formula $a d+$ accusative should suggest a place to rest rather than a vicus or a civitas (Roldán Hervás 1966); in this case ad Palmam would probably have been a statio located close to or within a date palm orchard.

The epigraphic text of the two milestones dated to the reign of Maximinus (AD 237) - one related to the first mile (Figure 2.A) and the other probably to the second or third (Figure 2.D) - provides details that may suggest the existence, at that time, of ruined bridges that had been restored (pontes vetustate delapsos et iter longa iniuria coruptum restituerunt). This is a common and stereotyped formula used frequently in several areas (Di Vita-Evrard 1979, 74; Romanelli 1970, 12-13) and apparently there is no evidence of bridges along the main Tripolitanian rivers (Mattingly 1995, 61). However, it would be plausible to consider the existence of viaducts across the main Lepcitanian watercourses (Goodchild 1948, 7, 9; Munzi et al. 2004, 30) due to the presence of several wadis with often steep banks and the high rate of traffic approaching Lepcis Magna. Recently, the existence of dams upstream on the coastal road has been also hypothesised (Munzi et al. 2004, 30), to protect it from floods. However, in my opinion, the use of dams to support roads must rather be excluded, apart from the great Wadi Lebda dam (Romanelli 1925, 72), due to their structural features - provided with lateral spillways and characterised by a reduced thickness on the top (see Vita-Finzi 1969, 20-24).

\subsection{The coastal road (south-eastern sec- tor) and traces of land partition}

The only archaeological evidence of the southeastern sector of the coastal road from Lepcis Magna are the traces recognisable from the historical documentation such as maps and aerial photographs and from the satellite images. Indeed, the closest milestone to the city was found outside the area investigated and is the one reused in the Sidi Mohammed ben Brahim mosque located c. $11 \mathrm{~km}$ from Lepcis Magna (IRT 929; Aurigemma 1925a, 19-21; IGM 1918a). The milestone, dated to
Caracalla, is incomplete and the mile number is not preserved; however, due to its find-spot, it could mark the seventh or eighth mile.

According to the Itineraria the distance between Lepcis Magna and the centre of Sugolin/Seggera to the south-east was 15 miles (Tabula Peutigeriana) or 20 miles (Antonine Itineray), thus located in an area between Wadi Caam, the famous Cinyps flumen, and the modern city of Zliten that has been identified, precisely, with Sugolin/Seggera (Desanges et al. 2010, 220). The flat sector between Lepcis and Wadi Caam, one of the most fertile areas of ancient Tripolitania, was surely crossed by a coastal road since the first Phoenician/Carthaginian settlers occupied the region. Strabo (17.3.18) mentioned some sort of infrastructures on this strip of land, including probably a road: 'Next (from Lepcis) in order one comes to a river (Wadi Caam); and afterwards to a kind of cross-wall which the Carthaginians built, wishing to bridge over some gorges which extend up into the interior' (translation and edition by H. L. Jones, 1967).

The position of the eastern caput viae at Lepcis Magna is actually not identifiable but, since the built area reached Wadi Lebda at least from the beginning of the second century $\mathrm{AD}$, it is possible to consider its position somewhere in this area and most likely at the intersection between the coastal via publica and the southern road (Figure 2). However, it is not surprising to hypothesise the position of the caput viae at the crossing with Wadi Lebda, taking into account the important role of rivers and bridges as capita viarum, as suggested by several examples in Gallia Cisalpina (Calzolari 2002). ${ }^{4}$

The traces of the coastal route are unfortunately missing from the sector between Wadi Lebda and the west limit of the es Sahel area. However, by analysing the recent satellite images, a WWII RAF aerial photograph (BSR, WP G11-62), and also according to the photo-interpretation made by Richard Goodchild during the late 1940s (1948, 9; 1949, 38; Figure 5), the ancient coastal road would be clearly visible in the following section, that is between the west limit of es Sahel oasis and Wadi Hasnun. In this segment the ancient road overlaps with an old Arab track that is still in use even if it has been asphalted (Figure 6). Once past Wadi Hasnun the 'via Litoranea' seems to overlap with the ancient road up until Wadi Caam (c. $20 \mathrm{~km}$ to the south-east).

Contrary to what has been argued by Goodchild, the coastal via publica and the subsequent Arab track in the east sector between Lepcis Magna and Wadi Hasnun was not the exact extension of the city's 


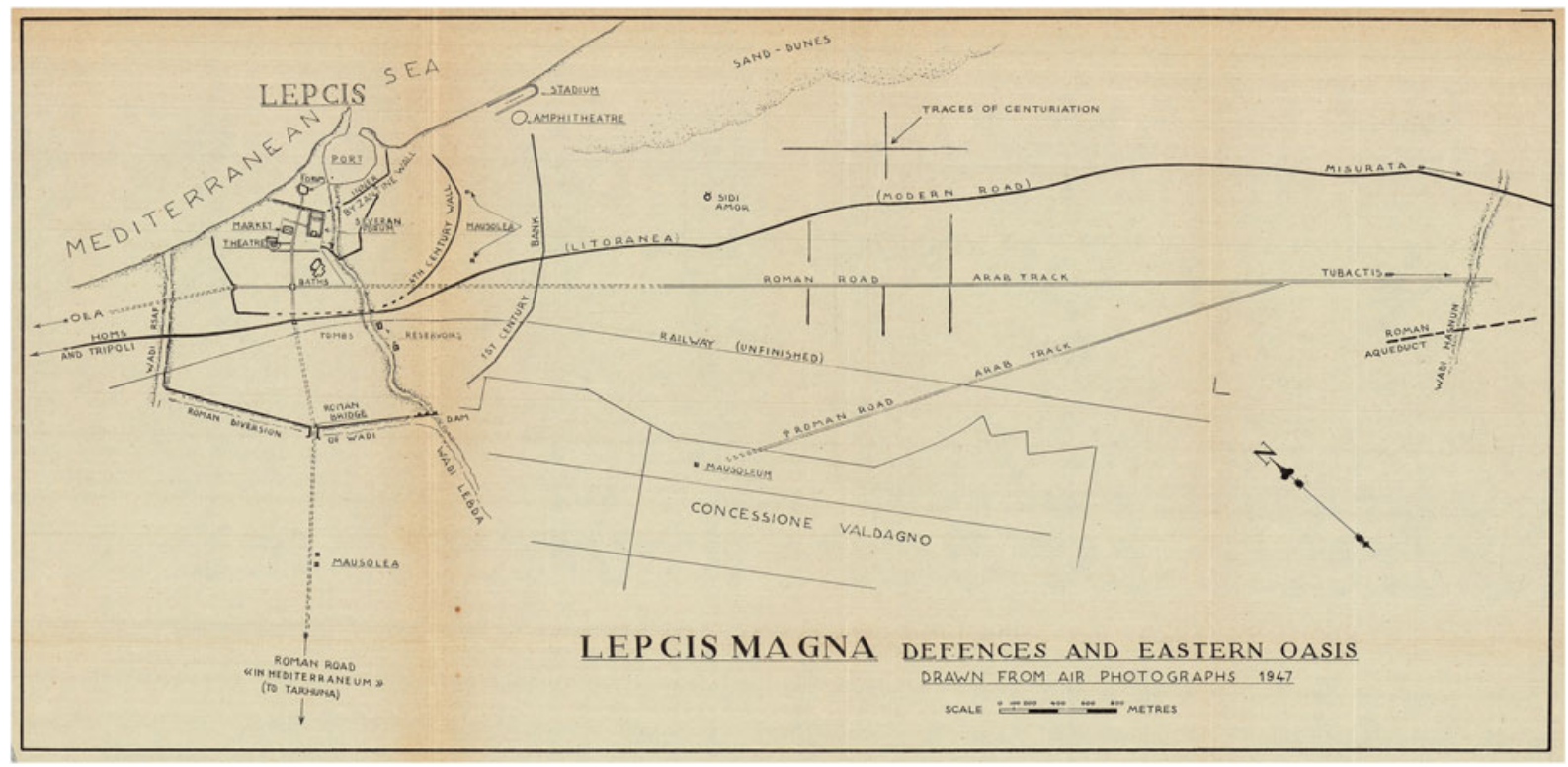

Figure 5. The suburban areas of Lepcis Magna according to Richard Goodchild (1949, plan 2).

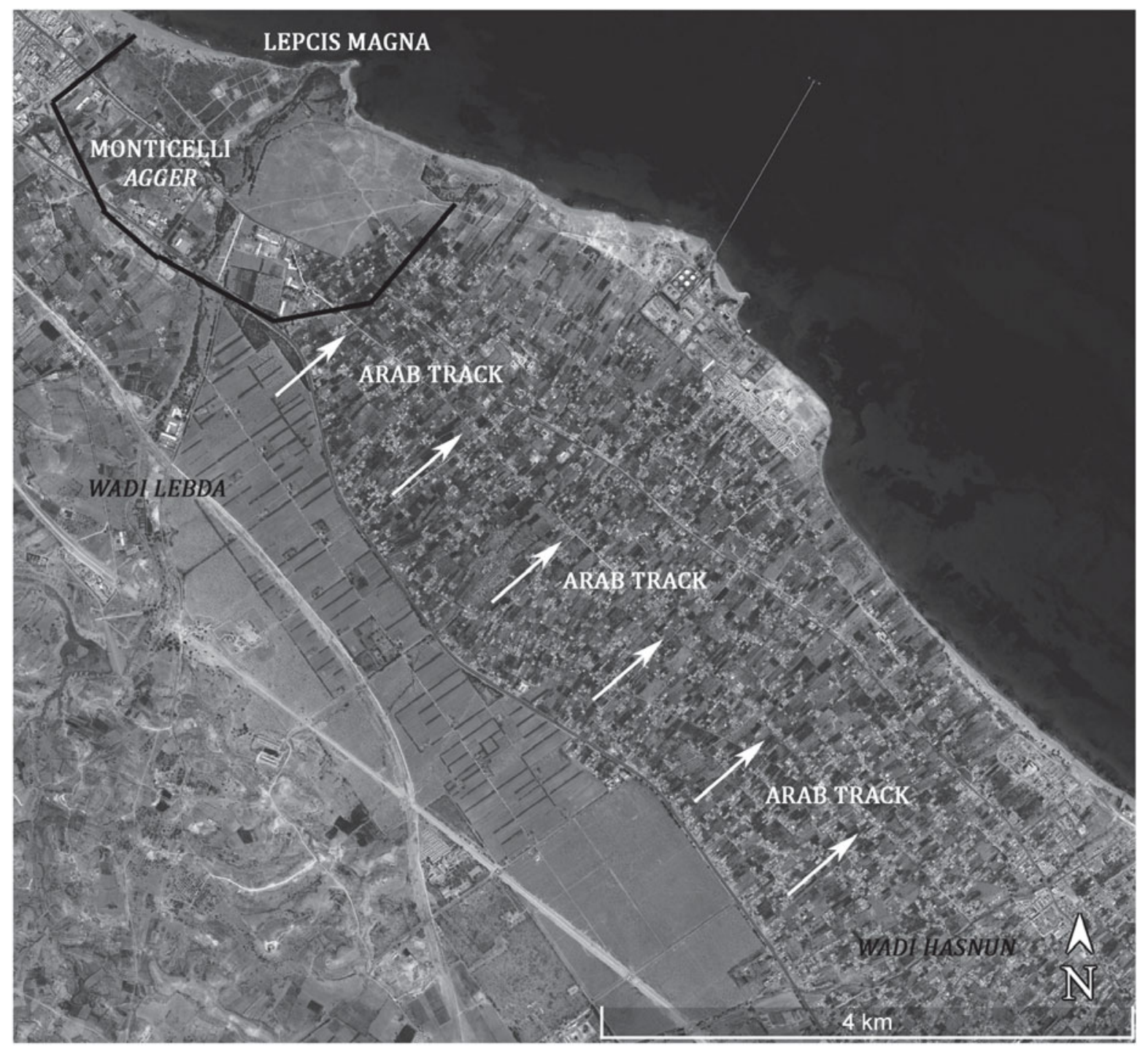

Figure 6. Traces of the Arab track in the sector between the west limit of es Sahel oasis and Wadi Hasnun. (Background image: Google Earth) 
decumanus maximus, but it diverged from it passing southwards and then, with a different orientation, continuing south-east. The orientation of the coastal road (if retraced by the Arab track) is indeed c. $8^{\circ}$ different from the city's main decumanus. These discrepancies related to the position and orientation of the peripheral decumanus had to be overcome in the short sector between Wadi Lebda and the beginning of es Sahel oasis where, however, there is no trace of the coastal via publica. The remains of the enclosure of the two mausolea known as Gasr er-Riyahi (Figure 7.A; Romanelli 1925, 163) and the enclosure of a third one (Figure 7.B), partially still noticeable on the ground but clearly visible in the IGM map (1915a) and in a WWII RAF aerial photograph (BSR, WP G11-62), could help in defining the course of this junction between the two sectors of the road. Both the funerary enclosures seem to follow the orientation of the hypothesised road from Wadi Lebda to the alignment defined by the Arab track. The two enclosures, the closest recognised to the proposed route and both dated to the second century $\mathrm{AD}$, would have an unusual orientation if not considering their relationship with the junction between Lepcis and the peripheral decumanus maximus, apparently the starting point of the organised land partition detected eastwards.

The reasons for the different orientation and position of the coastal road from the city's decuma$n u s$ (c. $8^{\circ}$ ) are unknown. However, it seems reasonable to think that the new alignment was more suitable to the Roman land partition that has been detected in the flat strip between the west limit of es Sahel oasis and Wadi Hasnun (for these aspects see Adam 2001 [1988], 12; Le Gall 1975; Regoli 1983; Tozzi 1974, 61-70).

A further proof of the prosecution of the coastal road retracing the Arab track is given by the numerous traces of ancient land partition that have been detected between the south-east sector of the 'Monticelli' earthen agger and Wadi Hasnun and that should have as its starting point the coastal via

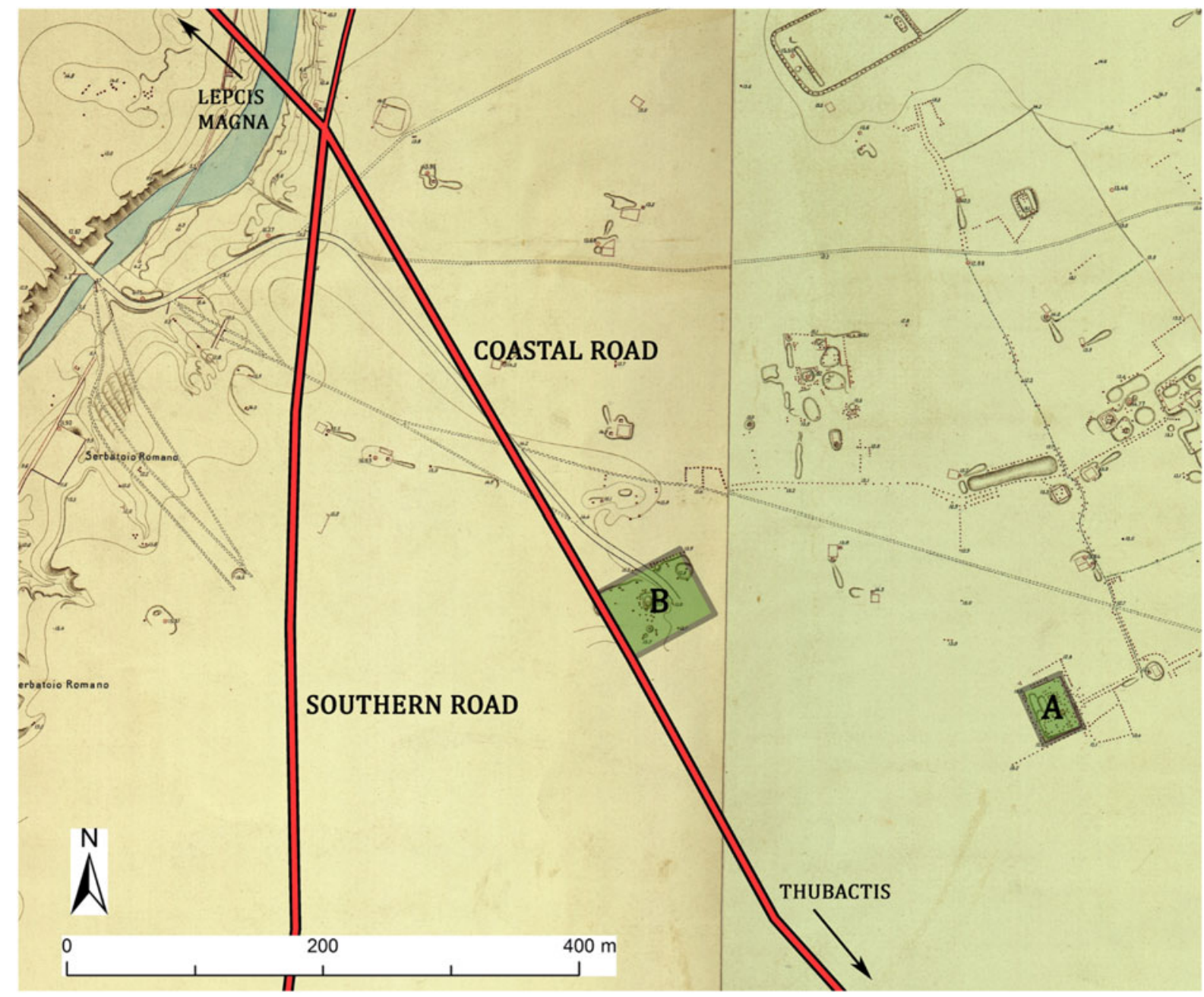

Figure 7. The first sector of the coastal road south-east of Lepcis Magna with the two funerary enclosures (highlighted) with the same orientation. (Background image: IGM 1915a-detail) 
publica (Figure 8). Several other traces associated with the same cadastre can be identified also further south-east, extending until Wadi Caam. Examining recent satellite images, it is possible to trace an ancient centuriatio based on the module of $12 \times 12$ actus (c. $426 \mathrm{~m}$ ) - with an internal subdivision of $6 \times 6$ actus (c. $213 \mathrm{~m}$ ) - thanks to several minor roads/tracks and also to tree or hedge alignments as well as modern boundary partitions (revealed also by the construction of houses that preserve specific alignments and positions). Unfortunately, no traces are visible of this ancient cadastre in the areas north and north-east of Ras el-Hammam due to the establishment of the Italian colonial settlement named 'Concessione Valdagno' during the 1930s.

Even though the area covered by this ancient limitatio has been overbuilt, especially in the last 40 years, the historical maps are in some cases useful in defining this partition. Indeed, some traces noticed in the satellite images overlap the ones outlined in two IGM maps dated to 1918: the accurate one $(1: 10,000$ scale) related just to a limited portion north of Ras el-Hammam (IGM 1918b) and the 1:50,000 scale map of the 'Zona di Homs' (IGM 1918a). Further traces overlap the ones in the 1:50,000 scale maps realised after the 1950s (SPLAJ 1979a; USACE 1962). On these maps are drawn both tracks and paved/unpaved roads that in several areas seem to retrace ancient boundaries
(Figure 8). Moreover, part of the alignments detected seems to fit with the ones identified by Richard Goodchild at the end of the 1940s (Figure 5).

The land partition attested in this area (Figure 9) is based on the canonical Roman actus $(35.52 \mathrm{~m})$ and the module detected is a square of c. $426 \mathrm{~m} \mathrm{(12}$ actus) with an internal subdivision of at least four squares, each one with a side of c. $213 \mathrm{~m}$ (6 actus). The $12 \times 12$ actus 'centuria' (that corresponds to 72 ingera) seems to have been used since the mid-Republican Roman phase in several parts of the Italian peninsula such as Minturnae, Norba, Alba Fucens, Aesernia, Cubulteria, Ad Tricesimum and Forum Iulii (Andreani 2006; Chevallier 1974, 52; Dilke 1971, 85). This partition, based on a multiple of two, also fits with the further subdivision in iugera (2 actus quadratus) and heredia (4 actus quadratus).

The orientation of the Lepcis land partition is c. $42^{\circ}$ compared with the east-west axis. The reasons for this alignment could be explained mainly by the natural shape of the nearby coastline. According to Frontinus and Hyginus Gromaticus, the methods used by Gromatici to establish the orientation of the centuriatio and thus of the decumanus maximus (or cardo maximus) were indeed also influenced by several geographical features and not only by the astronomic orientation (Castagnoli 1958, 26-27; Chevallier 1974, 50-51; Filippi 1983a, 125-26;
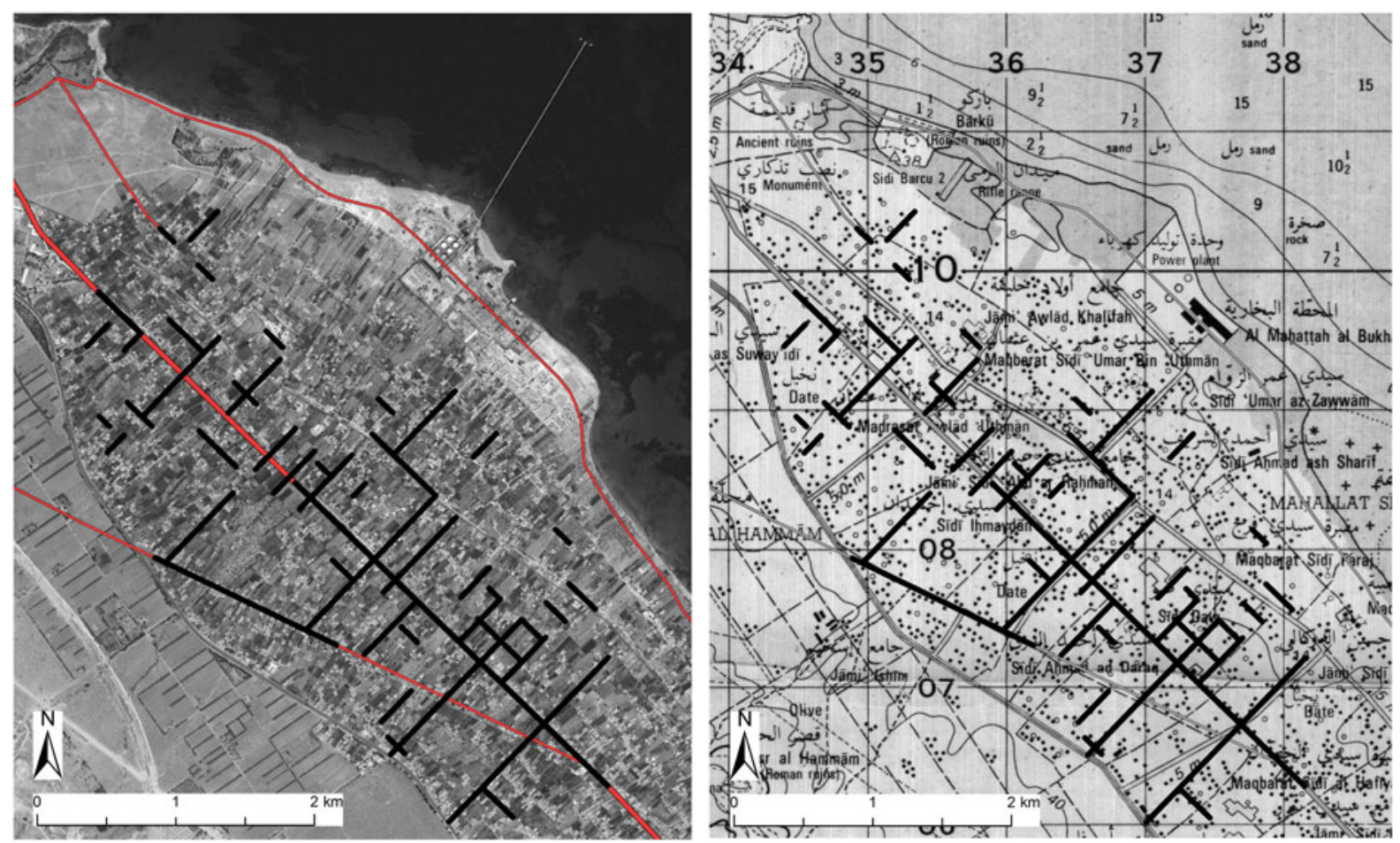

Figure 8. Left: Traces of ancient land partition detected on the satellite image (Google Earth). Right: The same traces of partially overlapping tracks and roads drawn on the Polish map (SPLAJ 1979a-detail). 


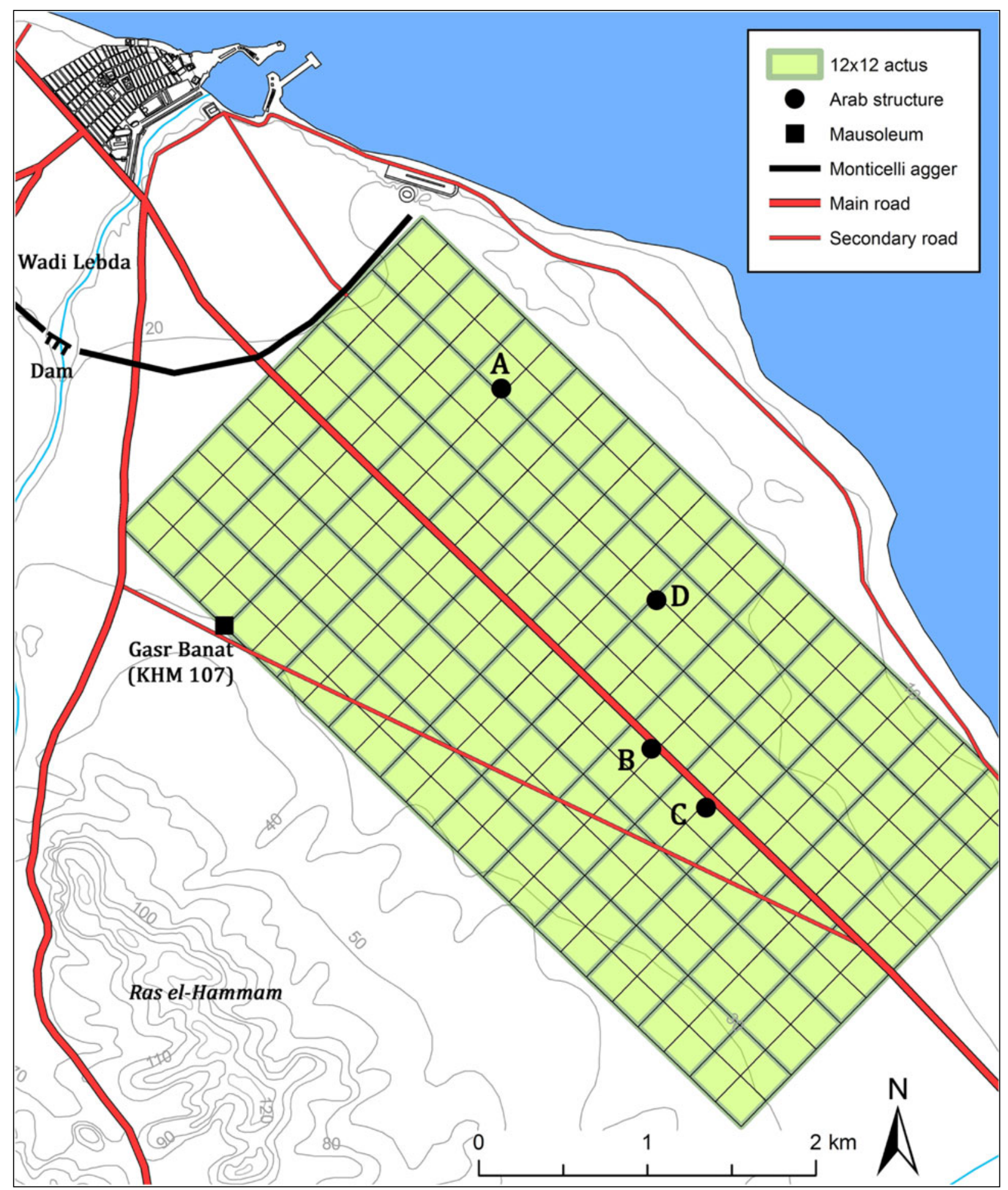

Figure 9. The hypothesised Roman land partition in the south-east suburb of the city with the ancient and Islamic structures associated.

Willi 2014, 144-49). In this frame, the sea or the foot of the hills may have constituted a valid border known as limes maritimus and limes montanus respectively and, in the area considered, both the mare Mediterranum and Ras el-Hammam's northeastern slopes have the same orientation as the hypothesised cadastre. In addition, according to the same sources, the terrain slope and the consequent water flow would act as a fundamental factor in determining the orientation.

Beside the traces still visible from the satellite images and confirmed by several maps, the module 
proposed seems also to be proved by archaeological evidence that can be connected in some way with this cadastral subdivision. A first element is given by the position of the 'Monticelli' earthen agger that seems to run along the limitatio to the northwest (Figure 9). The distance between the last row of centuriae to the west and the east of the agger is c. $30 \mathrm{~m}$, that is a reasonable space to house an external ditch and an associated path (the ditch was seen from the Wadi Lebda dam for c. $1 \mathrm{~km}$ to the east by S. Franchi in the first years of the Italian colonial period: MC 1913, I, 63). A further significant element is the position of the Gasr Banat mausoleum (Munzi et al. 2016, 91; Romanelli 1925, 49, 164 65) that is c. $1,275 \mathrm{~m}$ away from the coastal via publica right at the edge of the thirty-sixth actus south-west from it and exactly at the corner of the third $12 \times 12$ actus partition (Figure 9). We should also bear in mind that the role of funerary evidence as boundary markers in Roman times is commonly attested within centuriatio and land divisions in general and it is also indicated in the text De sepulchris collected in the Corpus agrimensorum Romanum (Lachmann 1848, 271-72; in general, see Castagnoli 1958, 11; Francisci 2010, 283; 2017, 57-64; Rosada 2010, 143; Sena Chiesa 1997, 286, 308-9). Finally, other minor ancient roads seem to adapt their routes according to the cadastral partition: the path that ran from the Severan harbour south-east and towards the diagonal road that linked the coastal via publica to the southern road (see Parts 3.1 and 3.3).

The position of some Islamic religious structures and of a funduq may constitute further indirect evidence related to this antique land partition. According to the Italian maps (IGM 1915b; 1918a; 1918b) and also to the subsequent American and Polish documents (SPLAJ 1979a; USACE 1962), the three main marabouts - Sidi Amor ben Otman (Figure 9.A), Sidi Ahmed ed-Dregh (Figure 9.B) and Sidi Bu Durghen (Figure 9.C) - with their associated cemeteries identified within the area of the hypothesised cadastre, plus the Milad ben Aamer funduq (Figure 9.D), were located along main ancient partition limites. The existence of old paths retracing the internal Roman subdivisions may have conditioned the places to build, for instance, holy tombs of the marabouts who, from the fifteenth century onwards, decided to live and preach within the coastal oasis. A similar connection between religious structures and ancient cadastres can be noticed for several rural Christian votive niches or chapels in northern Italy (Filippi 1983b, 138; Paoletti 1983, 266-67), where they seem to have replaced ancient shrines built at the countryside crossroads (compita pagana). However, for the Lepcitanian case study, due to the lack of any archaeological evidence, it is not possible to establish a direct relationship between ancient and modern religious structures. Nonetheless, it appears plausible to link the marabouts to the ancient paths/limites, a connection already highlighted by Raymond Chevallier $(1989,78)$.

Considering the lack of any epigraphic evidence, dating the Lepcitanian cadastre and the related redefinition of the south-east sector of the coastal road is not easy. However, on the one hand the use of Roman measurements instead of Punic ones could indicate that the project to organise, or reorganise, the fertile rural landscape south-east from Lepcis Magna was realised from the first century $A D$ onwards. On the other hand, the construction of the massive three-storey tower type mausoleum of Gasr Banat seems to be strictly related to the land partition as a boundary marker. According to the proposed dating of the funerary structure (the mid second century AD, see Munzi et al. 2016, 91), it is thus plausible to argue that this large land organisation (probably including an area that could at least reach Wadi Caam) was planned between the first century and the first half of the second century AD.

Possible contexts for relating this cadastre to wider territorial organisation include that realised under Vespasian after the severe boundary crisis between Lepcitani and Oeenses (see in general Di Vita-Evrard 1979, 77-81 = AE 1979, 648-49) and probably culminated in the concession of the municipal status to the city (AD 74-77; see Di Vita-Evrard 1984) or, alternatively and much more likely, it could be related to the granting of its colonial status during the reign of Trajan (AD 109-10; see Gascou 1972, 75-80). Moreover, the Lepcitanian case would not constitute the only example related to a limitatio process in Africa at the time of Trajan and Hadrian (see also ILS 9381 = AE 1904, 144; $A E$ 1942-43, 35; Cortés Barcena 2013, ns 66-67, 69). The use of Roman measurements, however, could indicate that the Lepcis land partition was realised after the granting of a new civic status. This suggestion came from the case of Thapsus in Byzacena where it seems that a cadastre based on the Punic cubitus $($ c. $51.5 \mathrm{~cm})$ was organised when the city was still libera et immunis, while at least two new land partitions based on the Roman actus where realised subsequently, after it gained colonial status (Briand-Ponsart and Hugoniot 2006, 89; Ouni et al. 1995). However, it is not surprising to believe that at Lepcis in both cases - the concession of the municipal or colonial status - the land partition 
detected probably overlapped with a previous one considering the vicinity to the city and also the favourable morphological situation that had encouraged exploitation of this fertile area since the pre-Roman period.

Moreover, it is important to bear in mind a further significant aspect that may help and prompt us to date this Lepcitanian land partition between the end of the Trajan dominion and the beginning of Hadrian's reign: the water management activity that interested the city in those years, primarily the effort made by the well-known Lepcitanian notable Q. Servilius Candidus in AD 119-20 to bring the water to the city from Wadi Caam through a subterranean aqueduct (sua impensa aquam quaesitam et elevatam in coloniam perduxit: IRT 357; see also IRT 358-59). This important infrastructure that would have supplied water to the Hadrianic baths (and probably not only them) had surely also involved a strip of land that coincided, in the area close to Lepcis, with the cadastrian land partition just detected and that probably continued towards the south-east (the closest section of the aqueduct towards Lepcis has been found at Wadi Hasnun; see Figure 5; Bartoccini 1926, 47-38; 1927b, 99100, fig. 33; 1929, 72-74; Cifani and Munzi 2003, 91-94; Crova 1967, 112-14; Haynes 1981, 99100). According to Bartoccini $(1929,73)$ and to G. F. Lyon (1821, 337), the underground aqueduct was provided with large wells (foramina) about every $80 \mathrm{~m}$ (Bartoccini) and this may have constituted significant modifications to the above ground landscape that would suggest a contemporary new limitatio and land assignment (for hydraulic structures and Roman division grids, see Willi 2014, 150-54). Moreover, even if this infrastructure was built mainly for the city's needs, it cannot be excluded that its water was also used for rural villas and estates located along and near its route (for this aspect, see Wilson 1999; 2008, 309-11). In addition, the construction of the dam along Wadi Lebda, recently dated to the Hadrianic period (Pucci et al. 2011, 175-77, 183; Tantillo and Bigi 2010, 15558 ), together with the use of the east sector of the Monticelli agger and ditch could be related with the new limitatio (Figure 9). It is likely indeed that the Wadi Lebda water surplus of the rainy seasons could be easily diverted to the east and used to irrigate the fields (archaeological evidence of the east sector of the earthen agger and its ditch come from the WWII RAF aerial photographs and from MC 1913, I, 63). This Wadi Lebda water regimentation would also be confirmed considering the fact that the Monticelli agger/ditch ended at the south slope of the hill of Sidi Barku (where the amphitheatre is), obstructing the floodwaters to flow into the sea.

\subsection{The inland route of the coastal road}

According to the analysis of archival documentation, recent satellite images and evidence from archaeological surveys, it is possible to identify an ancient route that linked Lepcis Magna to the hill of Ras el-Mergheb (Figures 2 and 10). Furthermore, from that point the road seems to have continued westwards reaching the southern slope of Ras el-Manubia, and then probably joined the coastal road a short distance from the sea (west of the area investigated). The role of Ras el-Mergheb and its nearness to Lepcis Magna in ancient times cannot be ignored and the importance of the structural traces that have been found on the hill suggest a route linking it to the city. Even if the remains of Ras el-Mergheb are poorly known, the presence

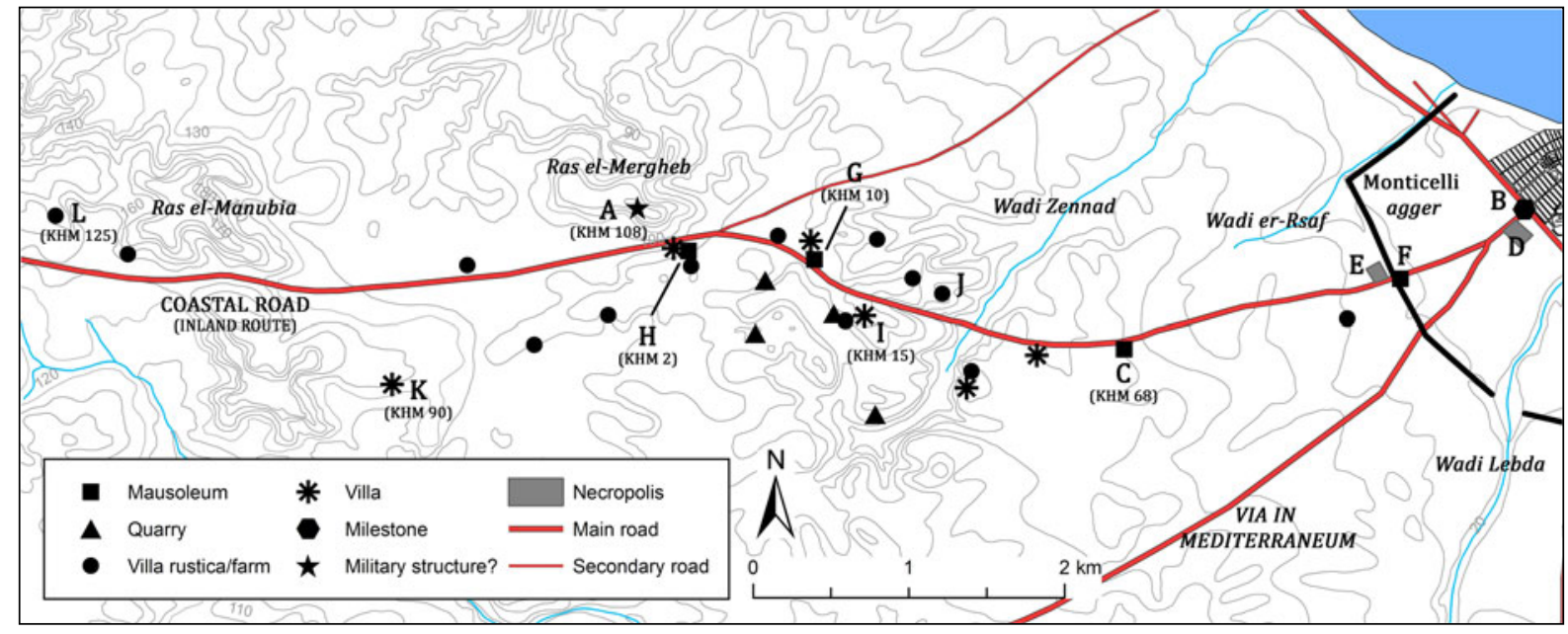

Figure 10. The inland route of the coastal road with the main sites close to it. 
across different centuries of quarries, religious evidence and a fortified installation (Figure 10.A) indicate the significant role of the site probably since the Punic phase (in general see Munzi et al. 2016, 74-75, 96).

The starting point of this route was the same as for the via in mediterraneum (see Part 2.4), that is where the Porta Augusta Salutaris was located and where the arch of Septimius Severus was subsequently built. It should also be remembered that beside the milestone erected by L. Aelius Lamia (Figure 2.H; IRT 930), another milestone dated to Domitian was found in the same area (Figures 2.I; 10.B; Reynolds 1955, 125, n. $3=I R T$ 975). Unfortunately, due to its poor state of preservation, it is not possible to establish if this milestone, most likely a caput viae, belonged to this road or to the 'East Gebel road'. However, specifying the direction of the path with the words in mediterraneum in Aelius Lamia's milestone could suggest the need to distinguish the two roads that, apparently, shared the same starting point.

The first c. $70 \mathrm{~m}$ of the road (from the Severan arch to the modern monumental step of the archaeological area) were dug during the Italian colonial period. The portion investigated showed that the route was here c. $8 \mathrm{~m}$ wide and paved with limestone slabs. However, there are no traces of wheeled transport on the surface of the passage; the presence of the monumental arch with steps up onto the road, hindered - at least from the beginning of the third century $\mathrm{AD}$ - the direct passage of carriages.

The first two miles (c. $3 \mathrm{~km}$ ) are clearly traceable thanks to the archival documentation: both the RAF aerial photographs made during the 1940s (ASLS,
Lepcis Magna 24996; BSR, WP G11-62) and the maps realised from the Italian colonial period onwards (IGM 1913; 1914; 1918a; SPLAJ 1979ab) indicate the presence of a path that is still clearly visible (Figure 11) and partially walkable as far as the site of the Gasr ed-Dueirat mausoleum (Figures 10.C; 11; Munzi et al. 2016, 87-88). The antiquity of this sector of the route is confirmed by the presence of several Roman funerary structures that have been built along its edges. South-west of the section of the road dug by the Italians mentioned above, the path was flanked by necropoleis partially investigated (Figures 10.D-E; 11) and by the mausoleum (Figure 10.F; Abd al-Rahman 1995, 155) built, it would seem, leaning over the 'Monticelli' earthen agger (Figures 10 and 11). According to aerial photographs and to the IGM map created in 1914, this earthen bank is discontinuous at the point where the route crosses it, further evidence of the antiquity of the road. It is unlikely that this passage through the agger was opened in the Arab/Ottoman periods given the scale of effort required to level it when there was certainly an already existing passage for the via in mediterraneum located a few hundred metres south-east (see Part 2.4). However, contrary to the crossing of the close via in mediterraneum with the agger's ditch, there is no archaeological evidence related to a bridge for this route (the area has recently been heavily overbuilt).

There are no clear traces on the ground for the rest of the sector that goes from the mausoleum of Gasr ed-Dueirat (Figures 10.C; 11) to the Ras el-Mergheb hill (Figure 10.A). However, once again, the presence of mausolea (Figure 10.G-H; Munzi et al. 2016, 87-88), funerary inscriptions

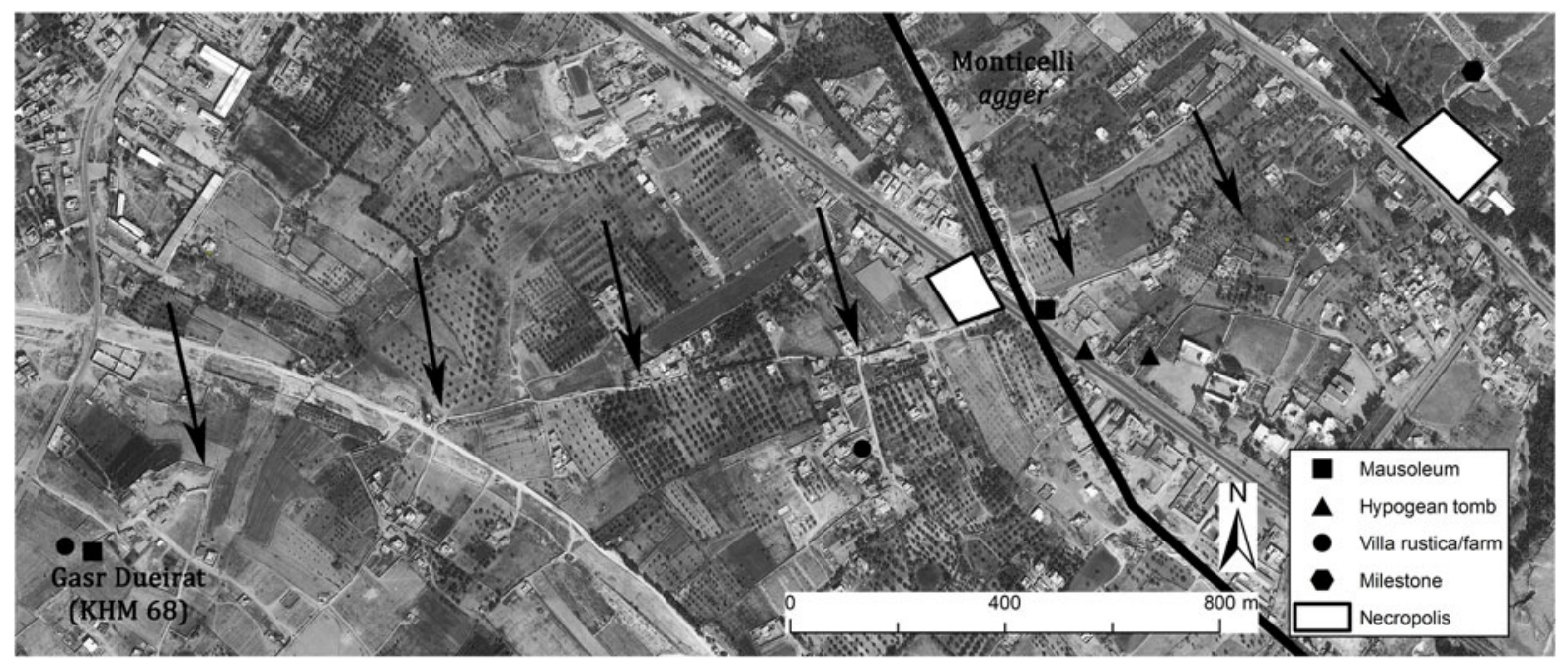

Figure 11. Traces (highlighted by arrows) of the first sector of the inland route of the coastal road. (Background image: Google Earth) 
reused in subsequent structures (Figure 10.I-J; Abd el-Aziz el Nemsi 1997, 207, 210-11; IRT 705) and the close proximity of sites of villae, villae rusticae and farms - recently detected by the University of Roma Tre survey - could help to define the ancient route that led just beneath the external Roman gate built on the hilltop of Ras el-Mergheb. This section of road was certainly also used by the nearby Wadi Zennad and Ras el-Mergheb quarry districts (Munzi et al. 2016, 76-79). There is an established connection between a type of large limestone ashlar block used in Lepcis and the quarries of Wadi Zennad, thus a road that linked these quarry faces to the city must have existed.

The section between Ras el-Mergheb and Ras el-Manubia is unfortunately poorly preserved in terms of archaeological visibility due to the cement factory and its related gravel and sand quarries (Munzi and Zocchi 2017, 61). However, the presence of a Roman villa (Figure 10.K) and of a fortified farm (Figure 10.L; Munzi et al. 2016, 73-74) on both sides of a valley together with the same morphological conformation of the area (a wide valley to the east and a narrow passage south of Ras el-Manubia) suggest that the route continued westwards from the hill of Ras el-Mergheb. Moreover, the modern Tripoli-Misurata highway retraced in this sector an older route attested since the Ottoman period (IGM 1886; 1913; 1918a) and that, in turn, probably overlaid an ancient one.

The ancient road probably continued west of Ras el-Manubia (outside the area investigated) for c. $3.5 \mathrm{~km}$ and, at short distance from Sidi bu Ghedir, it turned north following a valley that runs for c. $7 \mathrm{~km}$ towards the coast between Wadi Jabrun and Wadi Ganima. This valley is actually crossed by the modern Tripoli-Misurata highway (SPLAJ 1979b) but, according to the map attached to the account of the Commissione per lo Studio Agrologico della Tripolitania (MC 1913, I), it was crossed previously by an ancient caravan route (partially visible also in IGM 1915b). However, according to this hypothesis, the area where this inland route should finally join with the coastal via publica is at the twelfth/thirteenth mile. It is thus plausible to think that the junction between the two paths was situated at the statio named ad Palmam listed as 12 miles west of Lepcis Magna in the Peutinger Table. If so, this interior route could have replaced the coastal road avoiding the sand dunes and the wadis during the rainy season and ensuring the regular and fundamental cursus publicus of the North African east-west backbone.

\subsection{The via in mediterraneum}

Together with the coastal via publica, the via in mediterraneum is the only road mentioned by the Itineraria that reached Lepcis Magna. According to the caput viae set by L. Aelius Lamia (Figures 2.H; 12.A; IRT 930) during the reign of Tiberius, the ancient route from Lepcis headed south-west for 44 miles reaching the territorial border of the city identified near to Mesphe (Medina Doga; see Part 1). This sector of the route - the east end of the inner limes tripolitanus road - is quite well known and is attested by several different milestones (Di Vita-Evrard 1979, 69-73; IRT 931-38). Moreover, two boundary stones dated to Vespasian confirm the Lepcitanian western border indicated by the caput viae (Di Vita-Evrard 1979, 77-83 = AE 1979, 648-49).

The first eight miles of this route are included in the area investigated here and they can be traced with accuracy as far as Wadi es-Smara. A few ancient structures, together with some traces visible thanks to the archival documentation and to satellite imagery, help to define the path from its caput viae to the wadi.

From the Porta Augusta Salutaris the road initially shared the same path with the route that headed to Ras el-Mergheb (see Part 2.3). Once to the south of the administrative building of the Department of Antiquities of Lepcis Magna, it separated from it following a south-westerly direction to reach the ancient bridge (Figure 12.B) built over the ditch of the Monticelli agger. The unpaved track, still partially visible in the area south-west of the Department's offices, is indicated until the viaduct on the IGM map realised by Grupelli e Giua (IGM 1914). However, the construction of an airstrip in 1916 north-east of the Italian 'Forte Lebda', has obliterated the traces indicated on the IGM map.

The opus caementicium bridge (Figure 12.B), unfortunately recently destroyed, was c. $6.80 \mathrm{~m}$ wide and c. $20 \mathrm{~m}$ long (the span is c. $8 \mathrm{~m}$ ) and seems to have been the only ancient viaduct preserved in Tripolitania (Goodchild 1948, 7; Munzi and Zocchi 2017, 61; Romanelli 1925, 73; 1970, 22; Stroppa 1912, 72). From the Roman bridge the road turned gently south-west and then, probably after $500 \mathrm{~m}$, it aligned with a track that still runs a short distance south-east from a funerary area characterised by the mausoleum of Gasr Gelda (Figure 12.C; Munzi et al. 2016, 86-87), by another monumental structure (Figure 12.D) and by several inscriptions found nearby (Clermont-Ganneau 1903, 341-42; IRT 635, 657, 662, 755). With the 


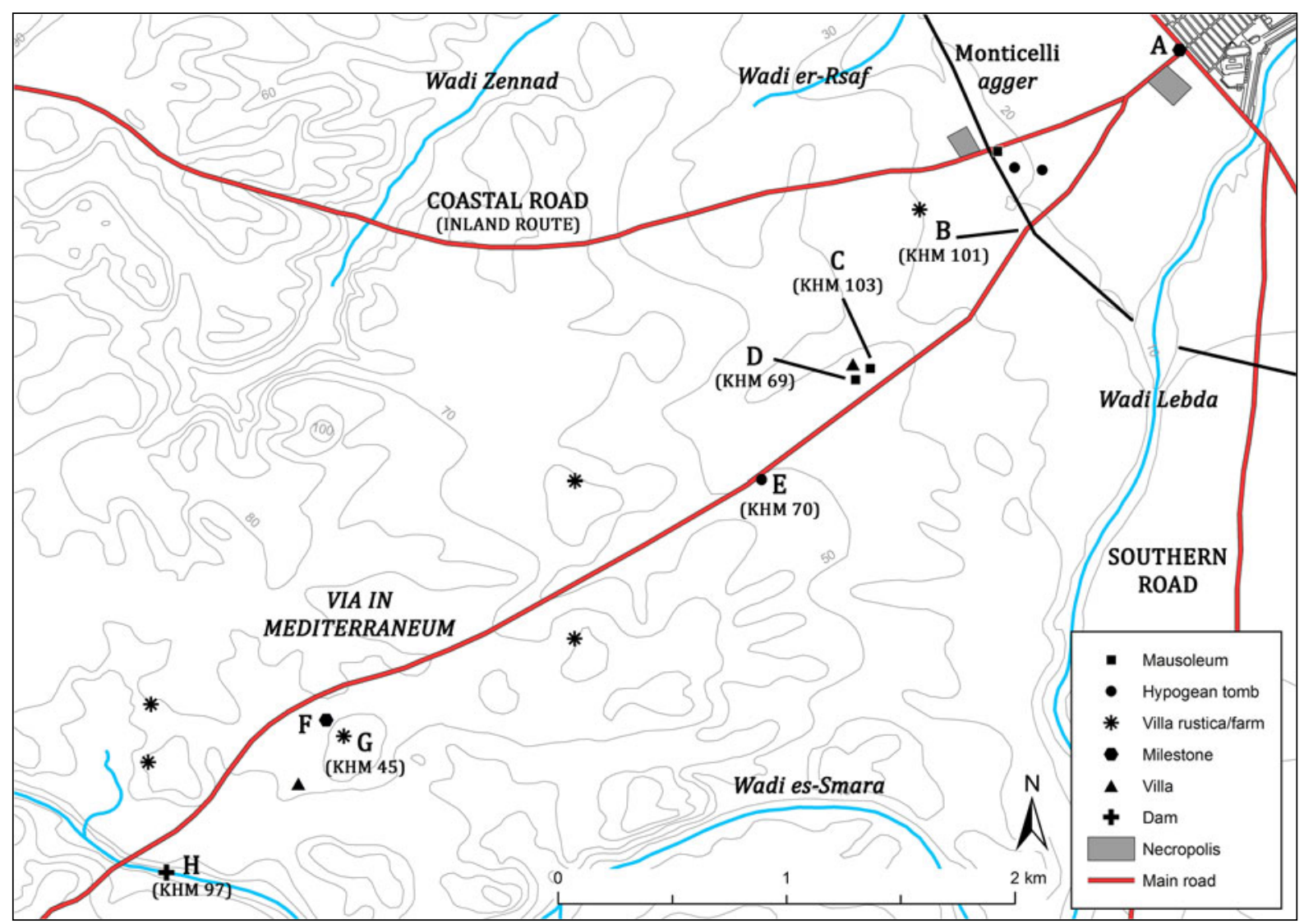

Figure 12. The first four miles of the via in mediterraneum with the main sites close to it.

same orientation, the route continued WSW for at least c. $650 \mathrm{~m}$ where a significant hypogean tomb dated to the Flavian period was found (Figure 12. E; Di Vita-Evrard et al. 1995; 1996). From this point, the traces of the track are missing; however a Caracalla milestone marking the second mile (Figures 2.J; 12.F; IRT 931) was found at a short distance from the ruins of Gasr Hammud (Figure 12.G; Munzi et al. 2014, 222). This find, together with some architectural elements belonging to a mausoleum reused as spolia within the same gasr, allow us to hypothesise that the ancient road ran a short distance from this Late Antique construction. According to the route proposed, this milestone was originally set c. $1.5 \mathrm{~km}$ from Gasr Hammud that is instead located a little further than the third mile (see Figure 2). Moving the column from its original position to the gasr (probably in a time span between the fourth and the sixth century AD) makes more sense if the road was close to both locations.

From the site of Gasr Hammud (Figure 12.G) the road continued towards Wadi es-Smara and then followed a south-westerly orientation, perhaps more or less retracing the old caravan route, actually asphalted, that led to Cussabat (IGM 1918a; SPLAJ 1979b). The crossing of Wadi es-Smara could, however, constitute an issue since it is one of the largest wadis in the area and the numerous ancient dams built along its bed suggest that it was certainly capable of moving considerable quantities of eroded material during the short rainy season. Even if there is no evidence of the exact location of the crossing place, the wadi sector close to the proposed route is actually one with the slightest slopes, a factor that could ease the crossing without the aid of a viaduct. Furthermore, it cannot be excluded that the nearby opus caementicium dam (Figure 12.H; Vita-Finzi 1969, 29-31, fig. 5b n. V) acted as protection for this road from periodic floodwaters (in this case it has to have been positioned west of the route), a hypothesis that has recently been proposed for the western wadis of the Lepcitanian area (Munzi et al. 2004, 30).

\subsection{The southern road}

The finding of a milestone base (Figure 2.K) together with some traces detected on RAF aerial photographs taken during the 1940s, suggest the existence of a road that headed southwards from Lepcis Magna (Figure 2). Indeed, it would appear quite 
strange if a wide portion south of the city was not directly linked to the coast in a similar way to the area served by the other roads just described (see Figure 1). This archaeological lack was already noted by Goodchild $(1948,28-29)$, who indeed proposed the existence of a track between Lepcis and the area of Beni Ulid. Moreover, as shown by different surveys (Barker et al. 1996; Mattingly 1995, 7788, 144-53; Munzi 2004), the area between Wadi Taraglat and Wadi Soffegin basins revealed a rich and agriculturally well-developed territory in ancient times with additional significance in terms of Roman military control, all factors that necessitated a direct and safe connection with the coast and with the city.

Even if the archaeological traces of this route are limited to only the very first sector, the recent and unpublished discovery of a milestone base in itself would suggest the importance of the road and that it probably continued for a considerable length, at least until the Msellaten area, probably towards the quadriburgus known as Gasr Bularkan (Barker et al. 1996, II, Md2; see also Figure 1). It seems strange, however, that no traces of other milestones have been found along or near the supposed route in the further sections.

The milestone base (Figures 2.K; 13.A) was recently found among the scattered finds related to a Roman mausoleum (Figure 13.B) located at the western hill foot of Ras el-Hammam. The base is characterised by a limestone parallelepiped with a circular socket to house the column's shaft (Figure 14); the diameter of the recession is c. 40 $\mathrm{cm}$, similar to many of the milestones set up by Caracalla in the region. Even if there are no further elements to establish an accurate date, the beginning of the third century AD would be a reasonable hypothesis considering the efforts made by the Severan dynasty to reorganise the whole system of the limes, including the road network (in general, see Mattingly 1995, 77-83). The base was not in situ; however, its original location had to have been pretty close as it came to light thanks to mechanical works realised recently alongside a modern road running few metres east from the mausoleum (Figure 13.B).

The course of this road cannot be traced with accuracy. However, some traces visible by analysing the aerial photographs dated to the 1940s (ASLS, Lepcis Magna 24996; BSR, WP G11-62, WP G11-61a) and funerary evidence would suggest its starting point just on the east bank of Wadi Lebda, precisely at the crossing with the decumanus maximus. Beside the track visible in the aerial photographs, the route could also be confirmed by the

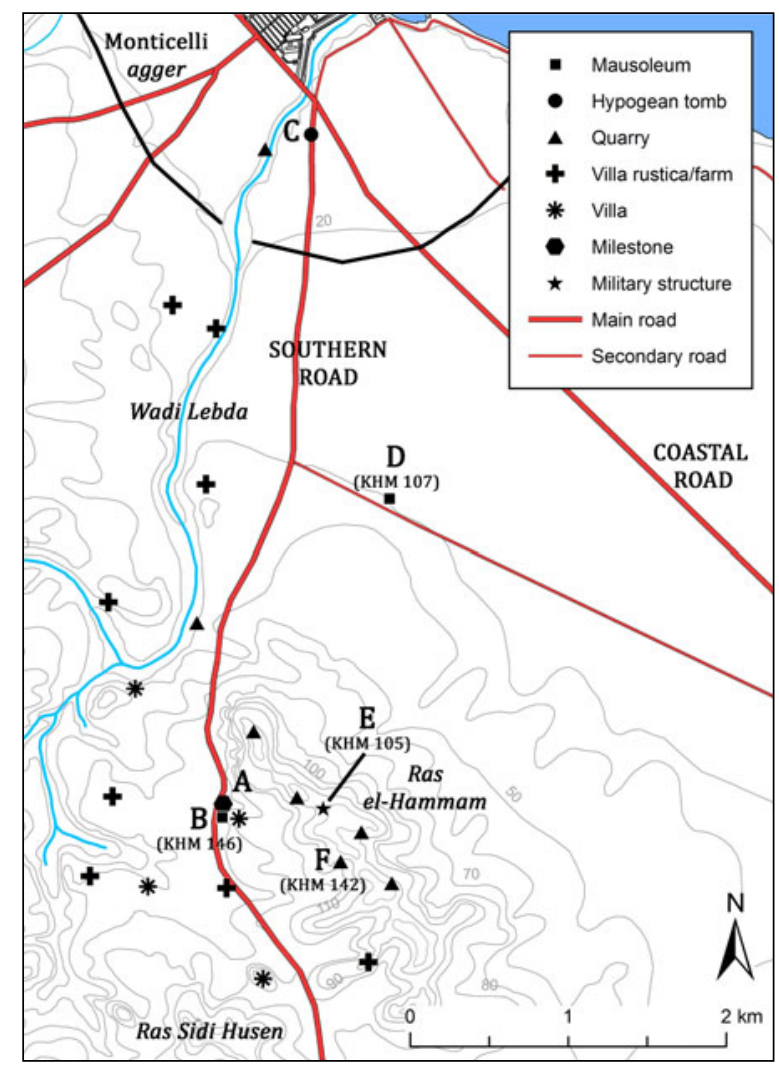

Figure 13. The southern road with the main sites close to it.

position of an unpublished hypogean tomb discovered in 1999 (Figure 13.C), ${ }^{5}$ whose grave goods can be dated from the first century $\mathrm{AD}$, and by the finding of a funerary inscription (IRT 633) related to a nearby mausoleum. We also have to bear in mind that the tall mausoleum named Gasr Banat, located c. $650 \mathrm{~m}$ to the east of the hypothesised southern route, had its facade looking west, that is towards this road (Figures 9; 13D). Moreover, a modern track with apparently the same orientation and position is also shown in the Lepcis map edited by Karl Müller (1855, tab. XXI).

If we assume that the caput viae of this road was situated at the crossing with the coastal via publical decumanus, it would then be convincing to state that the milestone base found near Ras el-Hammam marks with some precision the third mile (Figure 2). Moreover, the caput viae would be located a short distance from the hypothetical bridge over Wadi Lebda, supporting the significant role of rivers and thus bridges as capita viarum (see Part 2.2).

In the sector between the earthen agger and the northern slopes of Ras el-Hammam, the traces of the road detected in the aerial photos have been obliterated due to the construction of the 'Concessione Valdagno' settlement. Beside the finding of the milestone base, the path of the further 
segment, that is at the foot of the west flank of Ras el-Hammam hill, would instead be confirmed by the presence of the mausoleum (Figure 13.B), by numerous villae and villae rusticae located nearby and recently detected by the University of Roma Tre survey. It is also important to keep in mind that an ancient fortlet (Figure 13.E) was built along the Ras el-Hammam ridge and its position would easily fit with the importance of controlling both the southern road and the coastal via publica. The course of the route suggested here is also strengthened if we take into account the terrain morphology, characterised on the east side by the Ras el-Hammam hill and on the west side by the hills of Ras Sidi Husen and Ras el-Gattara.

Moreover, the presence of limestone quarries along the slope of the hills flanking its path constitutes an additional element that has to be taken into consideration (Figure 13). The track would have facilitated stone transportation to the city, especially for the quarries located on the west side of Ras el-Hammam where the extraction of very large ashlar blocks has been recently documented (Figure 13.F; Munzi et al. 2016, 80-82).

\section{The peripheral road network of Lepcis Magna: the minor routes}

A further two roads have been detected in addition to the main routes that led to Lepcis Magna from the different areas of Tripolitania. In both cases these paths, certainly less important in terms of length and traffic, acted as connections between

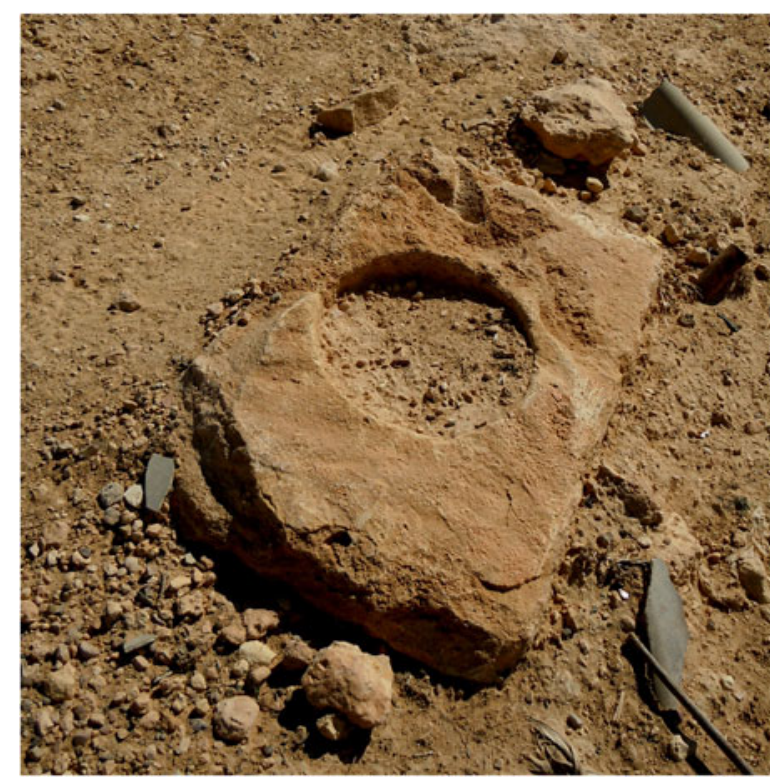

Figure 14. The milestone base found near the mausoleum and an ancient villa (KHM 146). (Photo: A. Zocchi, 2013) two of the main roads analysed above (see Part 2). One of these connected the coastal via publica east of Lepcis with the southern road, the other allowed travellers from Cape Hermaion and the coastal road to reach the inland route and the Ras el-Mergheb hill (Figure 2). Of course, several other minor roads or even footpaths must have linked different sites. Sometimes their evidence, since they were not provided with milestones or limestone paving (except in the immediate environs of the city), is suggested only by their relationship with ancient structures or by the morphological features of the terrain. Due to the difficulty of identifying these minor, and certainly numerous, roads it was considered appropriate to take into account only those that preserve some archaeological evidence or clear traces in the historical documentation.

\subsection{The junction between the coastal road and the southern road}

In the area east of Lepcis, and precisely in es Sahel oasis between the Tripoli-Misurata highway and the modern artery that retraces the ancient coastal via publica, is a tarmac road about $3 \mathrm{~km}$ long that preserves a different orientation compared with the other modern routes (Figure 15). This anomaly was already noted by Richard Goodchild (1949, 38), who was also able to analyse the WWII aerial photographs at his disposal (Figure 5). The British scholar suggested that this Arab track (not asphalted at his time) retraced an ancient route and perhaps acted as a bypass to avoid the city's main decumanus, where the passage of the wheeled transport was hindered by the presence of the Severan arch.

However, a few further topographic elements could be added to Goodchild's hypothesis and they seem to apparently confirm the existence of this road in ancient times. A first element is that the Arab track continued its route further to the northwest compared with the extent seen by Goodchild, passing by the mausoleum of Gasr Banat (Figure 15). The new cultivated fields set up within the Concessione Valdagno during the 1930s erased the track in the sector west of the funerary structure, preventing Goodchild from detecting it since he based his analysis on wartime aerial photographs; however, the maps made before the construction of the Italian settlement (IGM 1918a; 1918b) show that the path ran straight until shortly before Wadi Lebda, then crossed it and continued westwards. This ancient path should have continued at least until it joined with the southern road (see Figure 2), whose route was unknown to the British 


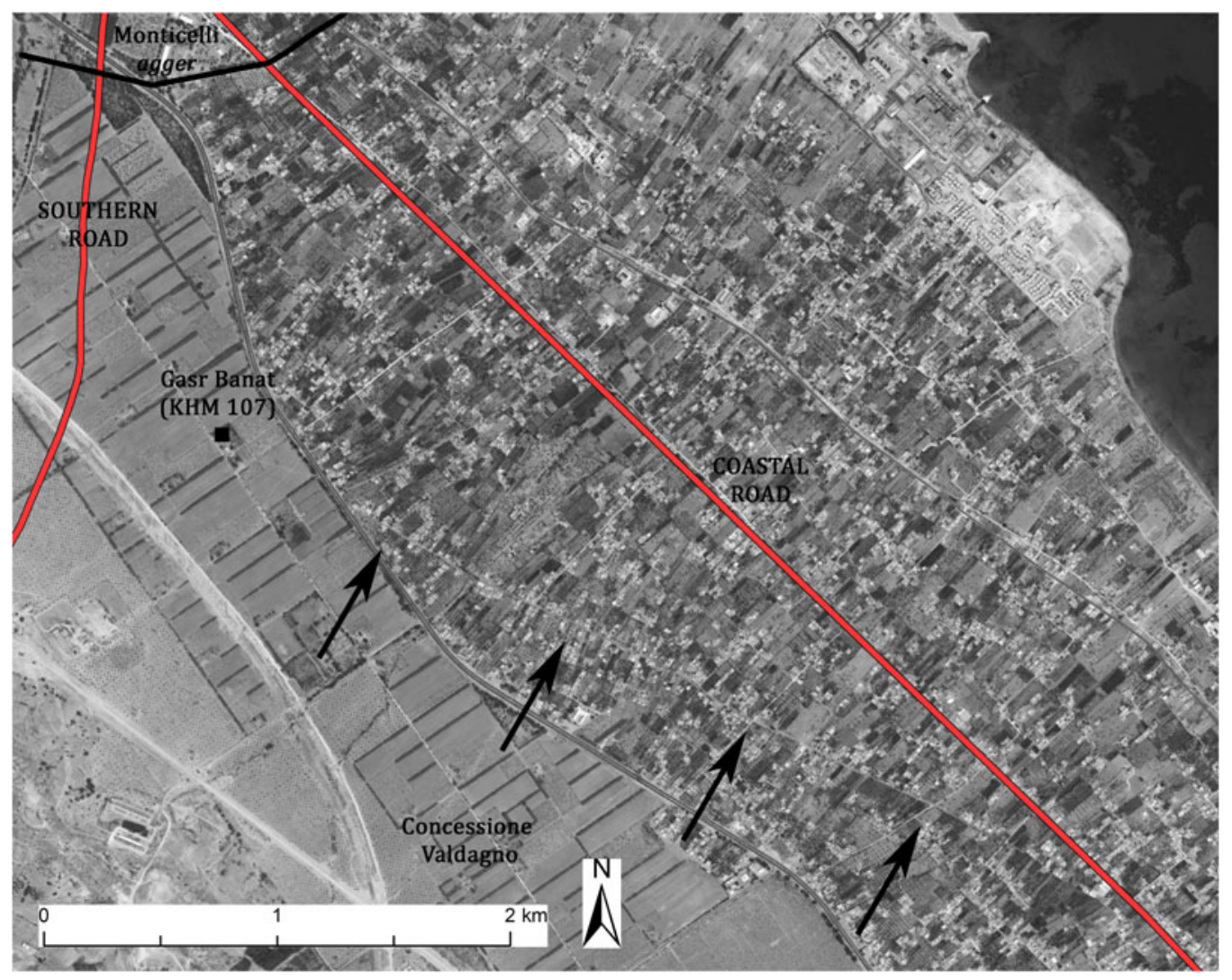

Figure 15. Traces (highlighted by arrows) of the junction between the coastal road and the southern road. (Background image: Google Earth)

scholar. Unfortunately, there are not enough elements to establish if this road did continue its route further, crossing Wadi Lebda and then linking with the other main routes to the west such as the via in mediterraneum and the inland route of the coastal road. This possibility would have allowed travellers to avoid entering the city and to save time, especially if needing to continue their journey in the eastsouth-west or east-west direction or vice versa.

The most convincing element that allows us to hypothesise with enough certainty the antiquity of this link road is its position within the cadastral partition detected in this area (Figure 9; see Part 2.2). This route, diverging c. $17^{\circ}$ from the coastal via publica, would cross the internal partition of 6 actus with a ratio of $1: 3$ (every 6 actus westwards this road deviated from the coastal via publica of a distance equal to 2 actus $=$ c. $71 \mathrm{~m}$ ). This ratio is not casual since in this way the route would have respected the corners of cadastral parcelling based on a multiple of 2 actus such as the heredium $(2 \times$ 2 actus $)$ and the iugerum $(2 \times 1$ actus $)$ and, at the same time, would also have avoided an overlap with the termini of the $12 \times 12$ actus partition, where probably the inviolable boundary stones were set, an expedient recognised in other similar cases (Muzzioli 2001, 12). The diagonal roads were common within the organised Roman land partitions and the different ratio between these courses and the cadastre is widely documented (Bottazzi 1988; Tozzi 1974, 44-60). However, a factor seems to be sure in this case: the diagonal road that linked the coastal via publica with the southern route was planned ex novo or retraced in relation to this parcelling.

A further element that would confirm the ancient origin of this course is the position of the already cited mausoleum of Gasr Banat, located at the corner of a $12 \times 12$ actus partition (Figure 9 and Part 2.2). Beside the will to mark a boundary it is now clear that the choice to build this funerary structure was also conditioned by the proximity $(\mathrm{c} .70 \mathrm{~m})$ of this diagonal road.

\subsection{The road from Cape Hermaion to Ras el-Mergheb}

According to traces detected both on the satellite images and from the historical cartographic documentation, it seems reasonable to hypothesise the existence of a road between the area of Cape Hermaion (Khoms) and the hill of Ras el-Mergheb (Figure 2); this route, c. $4 \mathrm{~km}$ long, would have connected the coastal via publica to the inland route that 
from Lepcis Magna headed west. The reasons for this link can be explained in relation to the existence of a secondary harbour at Cape Hermaion, attested from at least the fourth to the second century BC (Figure 16.A; Di Vita 1974, 239-49). The importance of this area within the Lepcitanian suburban zone is also underlined by other subsequent findings and structures including lavish villae (Figure 16.B-D; Bartoccini 1927a, 226-32; Di Vita 1966, 81-82; 1974, 234-39, 248-49; 1990, 455-57; Matoug 1995), a necropolis (Figure 16.E; Musso et al. 2010, 61-62), funerary structures and finds (Figure 16.F-H; Bakir 1966-67, 249; Baldoni n.d.; IRT 753) and perhaps religious buildings/areas and commercial activities.

Beside evident traces detected on the satellite images, the route is clearly shown in the majority of the Italian maps related to the area surrounding Khoms (IGM 1886, 1913). Moreover, the northern part of its course also seems indicated on the map edited by Müller (1855, tab. XXI), the only one showing the area before Khoms was established.

According to the plan of Khoms realised in 1943 by the US Army Map Service (published in Munzi and Zocchi 2017, fig. 4), this track was retraced by the street named by the Italians 'via Donato Senna' (previously via Cussbat), a road that from the central square of the town (occupied earlier by the 'Turkish Building') headed to the south gate of the city (Porta Mergheb). The irregular course of the subsequent sector is still clearly detectable in the southern outskirts of Khoms and, actually, more than half of the whole path of the road has been lost beneath intense overbuilding. Just outside the built area some archaeological evidence such as a villa and probably the associated mausoleum of Gasr Ben Nasser (Figure 16.I; Munzi et al. 2016, 88-89) would confirm the antiquity of the route, still visible a few metres north-west of these ancient structures. Moreover, at the end of the nineteenth century, it seems that the same route was used by Charles Clermont-Ganneau, who noticed several funerary structures and probably other ancient remains along the path: 'Dans le trajet entre Khoms et El-Mergeb, j'ai encontré toute une série de magnifiques mausolées construits en forme de tours carrées, sur de monticules couverts de ruines' (Clermont-Ganneau 1903, 344).

The sector close to Ras el-Mergheb is less clear, however both the direction followed by the previous segment of the hypothesised road and the remains of two Roman villae located nearby (Figure 16.J-K) would enforce the hypothesis that this ancient

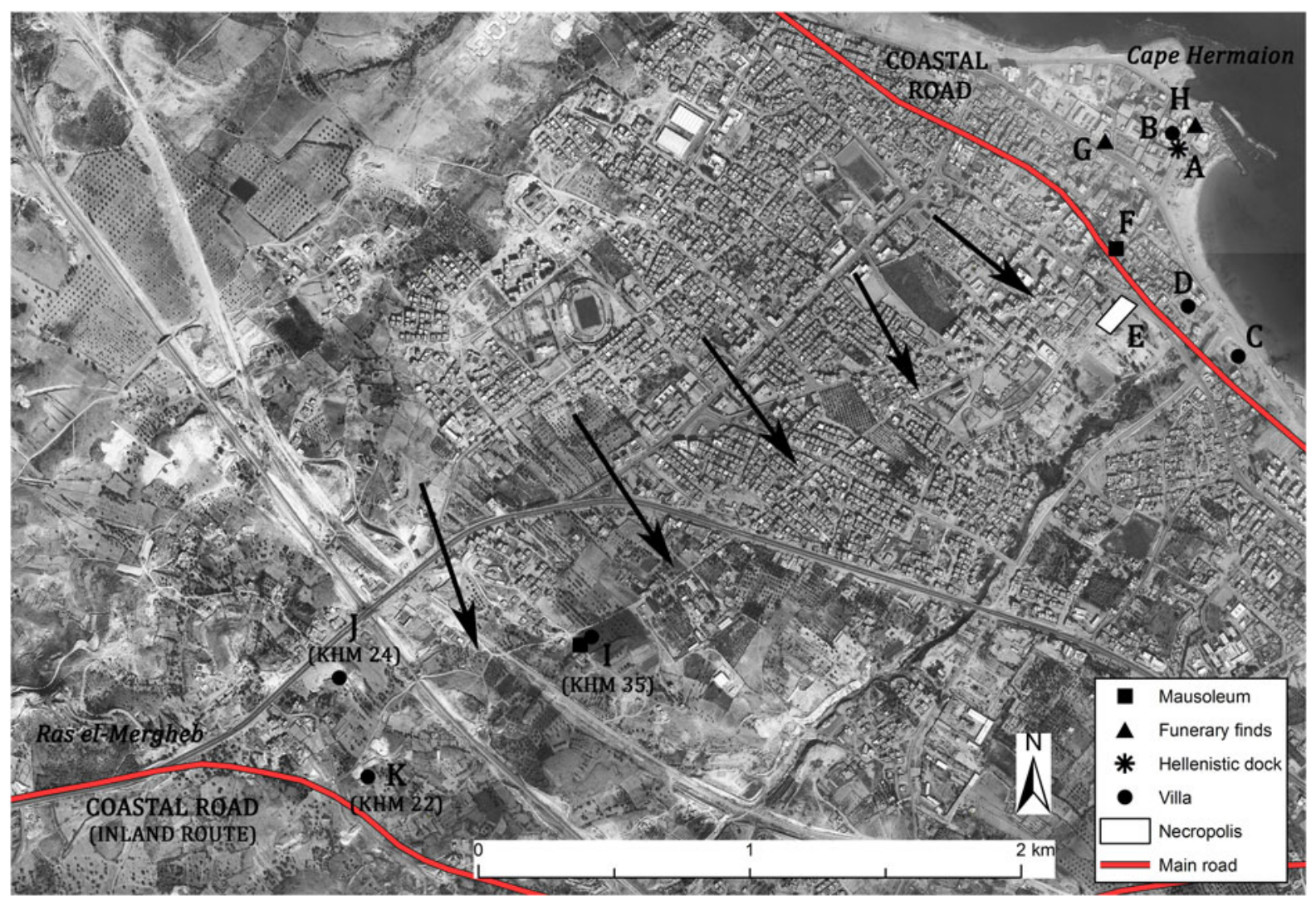

Figure 16. Traces (highlighted by arrows) of the road from Cape Hermaion to Ras el-Mergheb. (Background image: Google Earth) 
route continued with the same orientation and joined the main inland road south of the Ras el-Mergheb hill.

\subsection{The road system of the inner east suburbium}

The eastern suburban area of Lepcis defined by Wadi Lebda to the west, the 'Monticelli' earthen agger to the east and the Suk el-Khamis-Khoms motorway to the south contain numerous and considerable archaeological sites belonging to different categories (Figure 17). However, unfortunately, two main factors prevent a correct reading of the main topographic features such as the road network. On the one hand, there was considerable looting and destruction of ancient structures during the Italo-Turkish war in order to build forts, trenches and redoubts in the area (Munzi and Zocchi 2017, 51-52). This erased most of the ancient remains of wall alignments that could help to identify roads or paths. On the other hand, the lack of any extensive geophysical investigation such as a magnetometer survey hinders the analysis of the buried evidence; however, a recent preliminary survey was made in 2009 within the Ports Project, but it has not been published in detail (Keay 2010, 333-34). In addition to these factors, the actual use of numerous and wellfrequented footpaths makes it hard to distinguish between them and ancient ones. In view of all this, the only elements that could help define the evidence of ancient roads in this area are the detailed maps made by the topographers of the IGM (1914; 1915a) and a few archaeological remains or traces.

Two of the three sites related to roads that have been found in this area belong to a route that ran from the decumanus maximus/coastal via publica northwards to just west of Wadi Lebda (Figure 17). The route should have linked the main east-west axis with the Lepcis harbour without entering the city centre; from there it turned to the east and, at a short distance from the shore, reached the circus

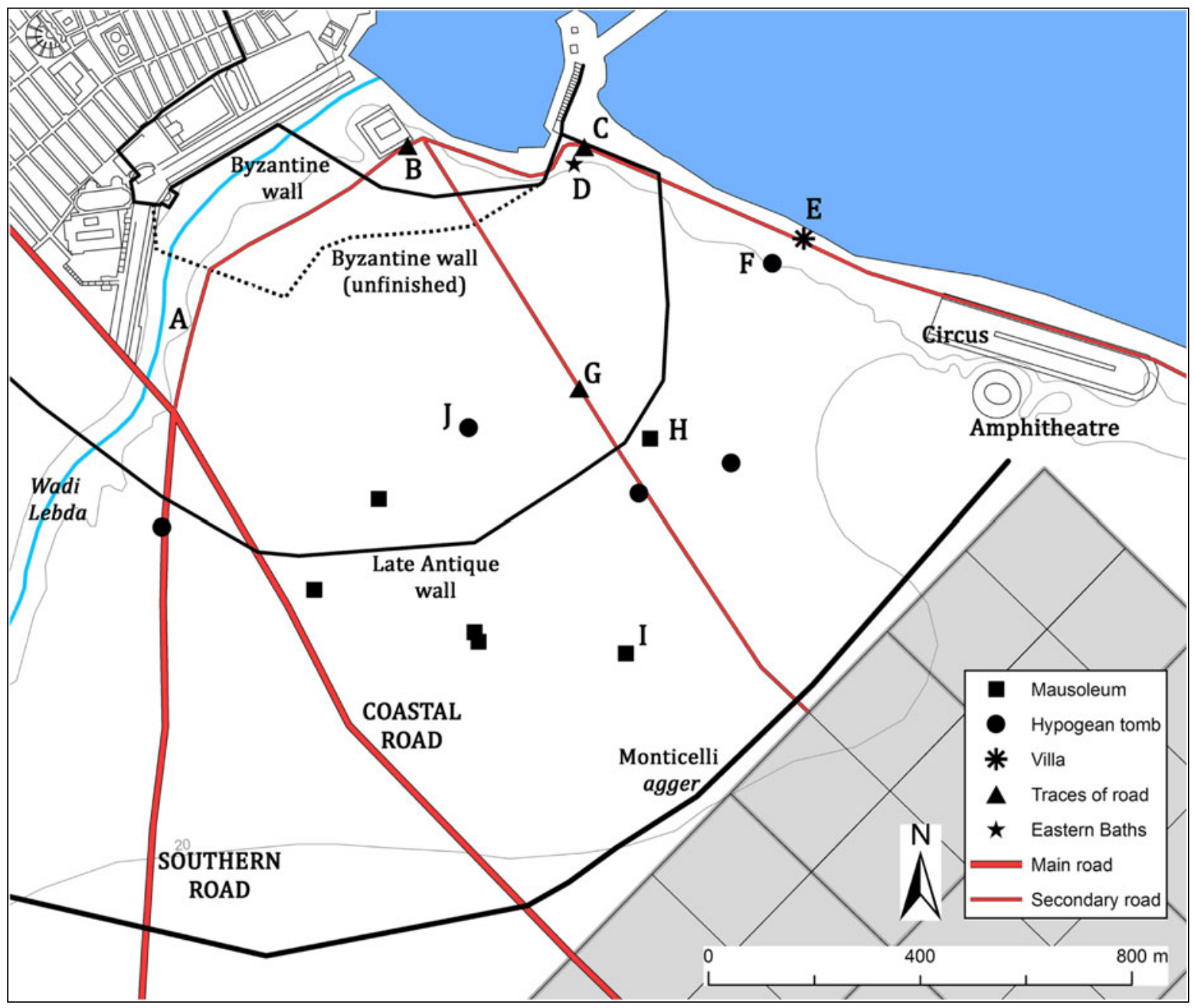

Figure 17. The road network in the inner east suburbium of the city with the main associated archaeological evidence. 
and finally it probably continued to the east (Figure 2). The first c. $300 \mathrm{~m}$ of this path, that is from the decumanus to the first moderate turn towards the north-east, seems to be traceable thanks to a series of wall alignments close to Wadi Lebda clearly visible in the IGM maps and in a WWII RAF aerial photograph (BSR, WP G11-61a; IGM 1914; 1915a). In particular, the 1915 map indicates a wide structure (c. $65 \mathrm{~m}$ long), unexcavated and probably provided with a portico, whose importance certainly would have required a direct road access (Figure 17.A). The further part of the route - until the east mole of the harbour - is attested by a section of the road (Figure 17.B) probably brought to light by Italian soldiers a short distance from the east side of the temple of Jupiter Dolichenus. The segment found is actually not visible anymore but an unpublished aerial photograph dated to 1919 discovered in the USAM Archive (Figure 18), shows that it was paved and c. $5 \mathrm{~m}$ wide; moreover, it is also clear that it curves gently, probably to align with the quay of the nearby harbour to the north. The road continued its course following the south-eastern quay of the Severan port and from there, through part of the east mole, it ran at a short distance from the coastline reaching the circus.

A further portion of the road has been dug recently by the French Archaeological Mission a few metres east of the harbour (Figure 17.C; Dagnas and Paulin 2010-12, 103-4). According to this excavation the route is here configured as a platea maritima with a portico on the inland side that faces towards a series of shops and stores as well as the vestibulum of a thermal area known as the 'Eastern Baths' (Figure 17.D; in general, see

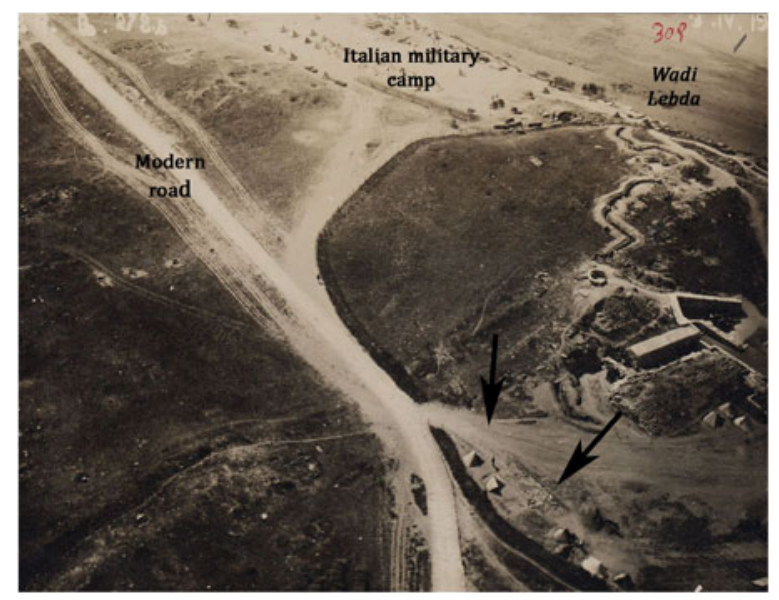

Figure 18. The remains of a paved road (highlighted by arrows) at a short distance east of the Temple of Jupiter Dolichenus, 1919 (USAM, Album Ufficio Storico nr. 5, 118-309).
Dagnas and Paulin, 2010-12). The sector has been cut on the north side by the Late Antique city wall, but the platea should have originally had a considerable width and probably acted as a quay. However, according to the function of the associated buildings and the nearness of the harbour, the road had to be heavily used in this sector during the mid and late Imperial Roman phases.

The further east segment linked the city to the circus, whose monumentalisation is dated to the mid second century AD. As already stated by Delaporte $(1836,332)$ at the beginning of the nineteenth century, this road sector - at his time partially visible - was flanked by both the structures facing the sea such as the 'Villa del Nilo' (Figure 17.E; Aurigemma 1929; Guidi 1933) and funerary monuments to the south, as attested by a first century AD hypogean tomb (Figure 17.F; Di Vita 1968, 58-61; IPT 63-66). In the sector just before reaching the circus, Romanelli $(1925,152)$ also reported finding three limestone bases (IRT 317) - dedicated to Juno and Venus by the gens Cassia - just beside the ancient road, however these were not visible at his time. Moreover, the portion of the road close to the circus, according to Cowper $(1897,210-11)$ and Méhier de Mathuisieulx (1903, 266), was flanked by other remarkable structures, now lost, identified as small temples and squared buildings with pilasters in addition to a great amount of columns on the ground.

Indirect evidence of the existence of the road comes from the circus: the presence of several entrances along its external north side would indeed confirm that the route ran in this area flanked on one side by the circus and to the north by the seashore (Humphrey et al. 1972-73, 29; Humphrey 1986, 27). There are no traces of the road in the section further east; however, both the report made by Romanelli $(1925,155)$, who cited the remains of several isolated houses and villae along the coast, and the excavation of a coastal villa located $2 \mathrm{~km}$ eastwards (Munzi and Zocchi 2017, 56) would suggest its continuation.

Traces of another road (Figure 17.G) have recently been detected in the central area of the east inner suburbium, c. $100 \mathrm{~m}$ south of the Italian stronghold 'Settimio Severo' (Figure 19). Unfortunately, the remains of this route are characterised by a few limestone slabs and it is not possible to determine its original width nor its orientation. However, thanks to its hypothetical extension both north-west and southeast, it is possible to establish with enough certainty its course. Extending the route north-west from the site of the limestone slabs and following a modern 


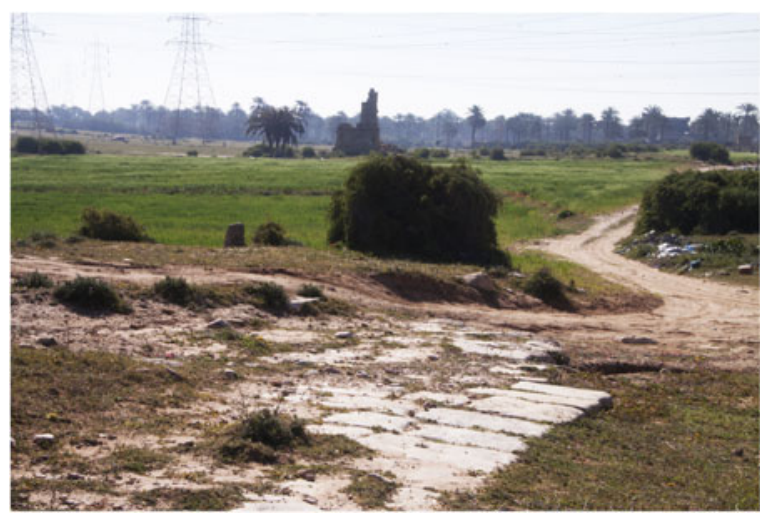

Figure 19. The remains of a paved road close to the mausoleum of Gasr Shaddad (in the background) and to the 'Settimio Severo' Italian fort. (Photo: F. Sciré, 2014)

path it would seem that the starting point of this road was the southern quay of the harbour; moreover, the hypothesised path would have had the same orientation as the Jupiter Dolichenus temple. To the southeast, extending the orientation, it would have reached - following the same modern path - the edge of the $6 \times 6$ actus partition of the cadastre detected just outside the 'Monticelli' earthen agger. There is another significant piece of evidence that would confirm the existence of this route: the coincidence between the road orientation with the wall alignments of the funerary structures close to it. This could be the mausoleum of Gasr Shaddad with its enclosure (Figure 17.H), but also the remains of the mausoleum of Gasr Sidi Bu Hadi (Figure 17.I) and the enclosure of a hypogean tomb (Figure 17.J) located south-west.

In addition to the evidence mentioned above it is significant that the hypothesised route runs parallel to the coastal via publica in its section between Wadi Lebda and the new alignment of the land cadastre to the east (see Part 2.2). Ultimately, from the analysis of the satellite images it seems that the majority of the structures located in this area followed, with minor variations, the same north-west to south-east orientation dictated by the two main road axes.

Without a doubt other minor roads crossed the same area and, for instance, it is highly probable that a route approached the amphitheatre from the south-west. However, any attempt to define a hypothetical course for it would be unfounded, as would any efforts to identify the small paths that from the main roads should lead to specific funerary structures.

Finally, it is important to consider that some modifications to this organised road network occurred with the construction of both the Late Antique and Byzantine walls; due to their construction some routes probably had to change their courses adapting to the closest gates, whose positions in this area are still unknown (for the defensive enceintes, see Goodchild and Ward-Perkins 1953).

\subsection{The road system of the inner west suburbium}

The north-west sector of the inner suburbs of Lepcis Magna and in particular the area defined by the Marcus Aurelius arch (Figure 20.A) to the east and by a large necropolis to the west (Figures 20.B; 3 . M; Fontana 1996, 80; Vergara Caffarelli 1954, 117) is characterised by ancient structures that are in most cases strictly related to the coastal road. All the sites that have a 'public' function such as warehouses (Figures 20.C-D; 3.N-O), probably a caravanserai (Figures 20.E; 3.P) and also the thermal building known as the 'Hunting Baths' (Figure 20.F), are situated within the narrow strip (c. $300 \mathrm{~m}$ ) between the main road and the seashore. The historical documentation together with archaeological remains allow us to identify at least two minor roads in the strip mentioned above. Both these short paths had their starting points at the Marcus Aurelius arch that, according to the find-spot of the first milestone (Figure 2.A; IRT 924), would have marked - at least from the second century $\mathrm{AD}$ onwards - the caput viae of the coastal road west of Lepcis Magna (see Part 2.1).

The first route linked the decumanus maximus/ coastal road to the Hunting Baths (Figure 20.F) and almost certainly it would have continued north, reaching the shore and probably joining with a west-east road heading towards the city. The main features of this paved route, which had a preserved total width of $5.50 \mathrm{~m}$, are clearly visible in the sector that has been excavated west of the thermal building (Figure 20.G; Ward-Perkins and Toynbee 1949, 166). On the opposite side a large building dated to the second century $\mathrm{AD}$ and characterised by a monumental entrance framed by two columns was already detected by the IGM topographers and marginally excavated during the 1930s (Musso and Bianchi 2012, 22-25). Although the function is not clear, its significance within the area certainly justified, together with the Hunting Baths, the provision of this paved road.

From the arch of Marcus Aurelius another road headed with the same orientation as the city's decumanus maximus for at least further $450 \mathrm{~m}$ north-west. Even if there is no actual archaeological evidence of this road, its course can be traced with certainty by analysing both the IGM map (1915; Figure 20) and 


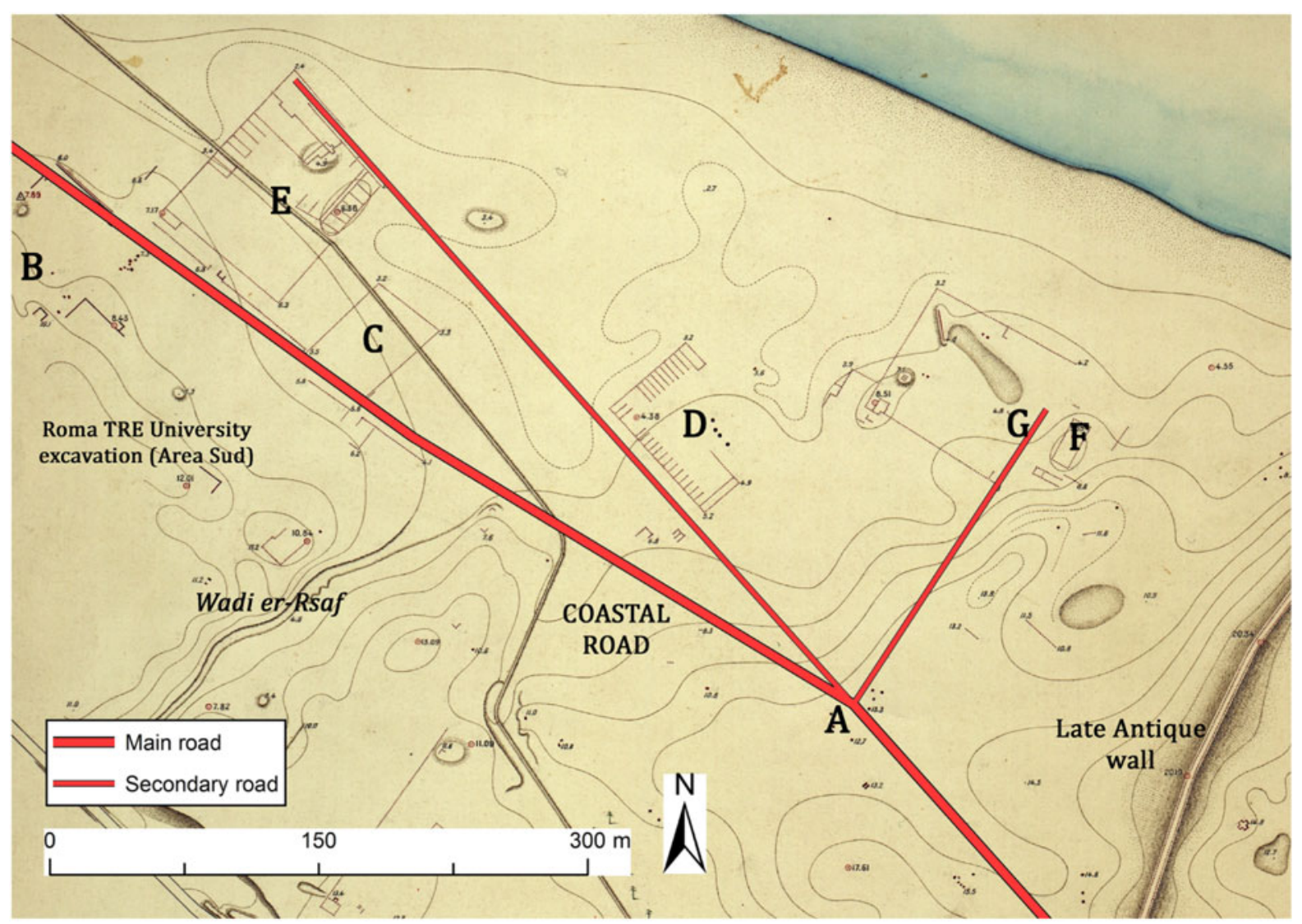

Figure 20. The road network in the inner west suburbium of the city with the main associated archaeological evidence. (Background image: IGM 1915a-detail)

an RAF aerial photograph taken in 1949 (ASLS, Lepcis Magna 24993). These documents show two large and important buildings, probably a caravanserai (Figures 20.E; 3.P) and the warehouses (Figures 20.D; 3.O), aligned with the extension of the Leptis decumanus (see also Jones 1989, 96-99; Mattingly 1995, 118 and fig. 6:1). The road may have deviated or stopped at the end of the caravanserai due to the convergence of the shoreline: probably it turned both to the left to repair the coastal road and to the right where it may have joined a hypothetical road situated very close to the sea and that headed to the western quays of the Lepcis harbour.

\section{Concluding remarks}

The analysis of the historical documentation, of the data gathered in several archives together with the data collected in the recent surveys carried out within the Archaeological Mission of Roma Tre University allows us to examine in depth the ancient Lepcitanian transport network and to update its status quaestionis, essentially based on the research done by the British scholars between the late 1940s and the 1950s. These updates covered both the main routes and other minor roads and have also enabled us to detect new tracks and to define, with better accuracy, the already known infrastructures.

The route of the coastal road north-west of Lepcis has been redefined thanks to the positioning of the milestones using a GIS platform (see Part 2.1). In this frame, the possibility to determine with accuracy the find-spot of the first milestone, set up a short distance from the eastern border of the modern city of Khoms, allowed to anchor, for the second/third century AD, the western limit of the urban area of Lepcis Magna (the caput viae) at the Marcus Aurelius arch.

A new reading of the east sector of the coastal via publica with a connected diagonal road has permitted us to consider a wide portion of the eastern suburbium as organised with a cadastral land partition based on the Roman actus in which both the coastal road and other minor routes played a fundamental role (see Parts 2.2 and 3.1). A new land organisation and definition of the inner south-east suburb (and probably until the Wadi Caam area) could also be linked with granting Lepcis Magna a new civic status under Trajan, when the municipium became a colony.

The recent and unpublished discovery of a milestone base together with other archival and survey 
data allowed also the definition of a new route that ran from Lepcis Magna and headed southwards, linking the coast probably to the rich Orfella region and to the farther limes (see Part 2.5). Even if the evidence is not so significant to hypothesise a road until those pre-desert areas, the new data presented in the southern periphery of Lepcis would help to fill a gap that to date kept separate the area of the Wadi Caam/Taraglat basin to the coastal city.

Thanks to significant traces visible on the historical maps, aerial photos and satellite imagery, and also thanks to the presence of several ancient sites located nearby, it was possible to detect and define another important route that from Lepcis Magna ran towards the hill of Ras el-Mergheb and, from there, continued westwards probably rejoining the coastal route at the statio named ad Palmam (see Part 2.3). This latter place could indeed be located on the crossing of these internal routes with the coastal via publica, in a zone where it is indicated by the Peutinger Table (12 miles west of Lepcis).

Finally, both the east and west inner suburban areas have been taken into account. In these cases, thanks to both the analysis of the scarce traces visible on the terrain and to a new examination of the archaeological remains, it was possible to define different zones (mainly funerary or connected to the movement of goods) delimited and developed thanks only to the road network that has now been taken into account (see Parts 3.3 and 3.4).

Lastly, one of the most significant elements related to this new topographical analysis of the Lepcitanian road network is that it constitutes a fundamental starting point and framework for examining the main aspects of this multifunctional ancient landscape in terms of population, economy and land exploitation.

Notes

1 Several sites mentioned in the text have been surveyed within the Archaeological Mission of the Roma Tre University directed by Luisa Musso in the area of Khoms between 2007 and 2013. The survey team was led by M. Munzi and was formed by the author and by F. Felici, I. Sjöström, E. Cirelli, G. Schingo and J. Matoug. The sites surveyed in these survey campaigns are indicated with the acronym KHM (Khoms) followed by their ID number in the figures.

2 A Lucius Verus bronze coin has been found on the road surface.

3 I am grateful to Luigia Marsico and Michele Cilla (Archaeological Mission of Roma Tre University in Libya) for making me aware of their existence.

4 According to Di Vita (1975, 23-26), at the edge of the west bank of Wadi Lebda, another monumental arch dated to Hadrian's reign was detected along the main decumanus by the assistant F. Russo. Probably this arch acted as caput via such as the Marcus Aurelius arch for the western sector of the city and the Severan arch for the via in mediterraneum.

5 I am grateful to Jabar Matoug (Department of Antiquities of Lepcis Magna) for making me aware of its existence.

\section{Abbreviations}

\section{$A E$}

ASLS

BSR

IGM

1886

IGM

1913

IGM

1914

IGM

$1915 \mathrm{a}$

IGM

$1915 b$

IGM

1918 a

IGM

$1918 b$

ILS

IPT

IRT

MC 1913

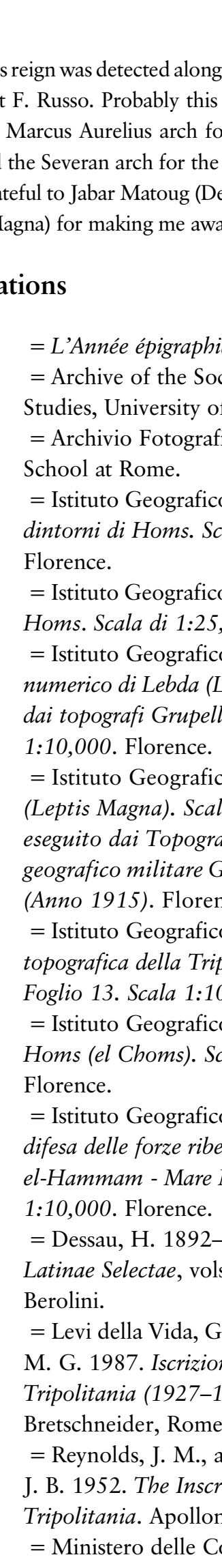
per lo studio agrologico della Tripoliti 1913. La Tripolitania settentrionale. Studi complementari ed illustrativi della relazione a S.E. il Prof. P. Bertolini, Ministro delle Colonie, vols 1-2. Tipografia Nazionale Bertero, Rome. 
SPLAJ

1979a

SPLAJ

$1979 \mathrm{~b}$
= PolService Geokart - Poland, Al Khums, sheet 2190 II, 1:50,000 scale. Warsaw. $=$ PolService Geokart - Poland, Misallātah, sheet 2190 III, 1:50,000 scale. Warsaw.
USACE

1962

USAM
$=$ United States Army, Corps of Engineers, North Africa - Al Khums, sheet 2190 II, 1:50,000 scale (P761 series). Washington, DC.

= Ufficio Storico Aeronautica Militare, Rome.

\section{References}

Abd al-Rahman, A. S. 1995. Latest tomb findings at Leptis Magna and in the vicinity. Libya Antiqua (n.s.) 1: 154-55.

Abd el-Aziz el Nemsi, M. 1997. Leptis Magna, excavation at az-Zeita (Wadi Zennad), 1996-1997. Libya Antiqua (n.s.) 3: 207-11.

Adam, J. P. 2001 [1988]. L'arte di costruire presso $i$ romani. Materiali e tecniche. Longanesi, Milan.

Andreani, M. 2006. Tracce di centuriazione alla foce del Garigliano. Agri Centuriati. An International Journal of Landscape Archaeology 3: 59-72.

Aurigemma, S. 1925a. Pietre miliari tripolitane - Parte I. Rivista della Tripolitania 2.1: 3-21.

Aurigemma, S. 1925b. Pietre miliari tripolitane - Parte I (Continuazione e fine). Rivista della Tripolitania 2.3: 135-50.

Aurigemma, S. 1929. Mosaici di Leptis Magna tra l'Uádi Lébda e il circo. Africa Italiana 2.4: 246-61.

Bakir, T. 1966-67. Archaeological news 1965-1967: Tripolitania. Libya Antiqua 3-4: 241-51.

Baldoni, D. n.d. Homs, la 'villa dello sparto': materiali della fase medio imperiale. Available at: www. mart-a.it/archives/232 (accessed on 18 July 18).

Barker, G., Gilbertson, D., Jones, B., and Mattingly, D. J. 1996. Farming the Desert: The UNESCO Libyan Valleys Archaeological Survey, vols 1-2. Society for Libyan Studies, London; UNESCO, Paris.

Bartoccini, R. 1926. Le antichità della Tripolitania. 'Aegyptus' 4. Tipografia Pontificia S. Giuseppe, Milan.

Bartoccini, R. 1927a. Rinvenimenti vari di interesse archeologico in Tripolitania (1920-1925). Africa Italiana 1.3: 213-48.

Bartoccini, R. 1927b. Guida di Lepcis (Leptis Magna). Società editrice d'arte illustrata, Rome and Milan.

Bartoccini, R. 1929. Le terme di Lepcis (Leptis Magna). Istituto Italiano d'arti grafiche, Bergamo.

Bottazzi, G. 1988. Le vie oblique nelle centuriazioni emiliane. In Vie romane tra Italia centrale e Pianura padana. Ricerche nei territori di Reggio Emilia, Modena e Bologna. Aedes muratoriana, Modena: 149-91.
Briand-Ponsart, C., and Hugoniot, C. 2006. L'Afrique romaine de l'Atlantique à la Tripolitaine. 146 av. J.-C.-533 ap. J.-C. Armand Colin, Paris.

Calzolari, M. 2002. Il calcolo delle distanze e i fiumi come capita viarum nei miliari dell'Italia settentrionale. Orizzonti. Rassegna di archeologia 3: 169-75.

Castagnoli, F. 1958. Le ricerche sui resti della centuriazione. Storia e Letteratura edizioni, Rome.

Cesàro, A. 1933. Santuari islamici nel secolo XVII in Tripolitania (Traduzione dall'arabo del 'Chitàb el-Isciaràt' dello Scech Abd es-Slam el-Alem et-Tagiùri). Azienda tipo-litografica 'Scuola d'Arti e Mestieri’ di Plinio Maggi, Tripoli.

Chevallier, R. 1974. Centuriation et cités en Afrique et dans l'arc adriatique. Antichità Altoadriatiche 5: 4368.

Chevallier, R. 1989. Roman Roads. B. T. Batsford, London.

Cifani, G., and Munzi, M. 2003. Alle sorgenti del Cinyps. Libyan Studies 34: 85-100.

Clermont-Ganneau, Ch. 1903. Lepcis et Leptis Magna. Académie des inscriptions et belles-lettres. Comptes rendus des séances de l'Academie 47.4: 333-46.

Cortés Barcena, C. 2013. Epigrafía en los confines de las ciudades romanas. Los Termini Publici en Hispania, Mauretania y Numidia. 'L'ERMA' di Breschneider, Rome.

Cowper, H. S. 1897. The Hill of the Graces: A Record of Investigation among the Trilithons and Megalitic Sites of Tripoli. Methuen \& Co., London.

Crova, B. 1967. Opere idrauliche romane all'uadi Caàm, il Cinyps della Tripolitania romana. Quaderni di archeologia della Libia 5: 99-120.

Cuntz, O. (ed.). 1929. Itineraria Romana. Volumen primus: Itineraria Antonini Augusti et Burdigalense. Tenbner, Leipzig.

Dagnas, G., and Paulin, M. 2010-12. Les Thermes du Levant à Leptis Magna: présentation architecturale et périodisation générale. Antiquités africaines 4648: 99-145.

Delaporte, J. D. 1836. Mémoire sur les ruines de Leptis Magna (régence de Tripoli de Barbarie), addressé en 1806 à M. le prince de Bénévent, ministre des 
relations extérieures de l'Empire français. Journal Asiatique, III séries, 1: 305-37.

Desanges, J., Duval, N., Lepelley, Cl., and Saint-Amans, S. (eds). 2010. Carte des routes et des cités de l'est de l'Africa à la fin de l'Antiquité d'après le tracé de Pierre Salama. Brepols, Turnhout.

Di Vita, A. 1966. La villa della 'Gara delle Nereidi' presso Tagiura: un contributo alla storia del mosaico romano ed altri recenti scavi e scoperte in Tripolitania. Supplements to Libya Antiqua 2.

Di Vita, A. 1968. Influences grecques et traditions orientales dans l'art punique de la Tripolitaine. Mélanges de l'École française de Rome. Antiquité 80: 7-84.

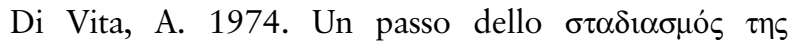
$\mu \varepsilon \gamma \alpha \lambda \eta \sigma \theta \alpha \lambda \lambda \alpha \sigma \sigma \eta \varsigma$ ed il porto ellenistico di Leptis Magna. In Mélanges de philosophie, de litterature et d'histoire ancienne offerts à Pierre Boyancé. École française de Rome, Rome: 229-50.

Di Vita, A. 1975. La ricostruzione dell'arco dei Severi a Leptis Magna in un disegno di C. Catanuso ed esistenza e significato di un tetrapilo preseveriano. Quaderni di archeologia della Libia 7: 3-26.

Di Vita, A. 1990. Sismi, urbanistica e cronologia assoluta. Terremoti e urbanistica nelle città di Tripolitania fra il I secolo a.C. e il IV d.C. In L'Afrique dans l'Occident romain (I siècle av. J.C. IV siècle ap. J.C.). Actes du colloque organisé par l'École française de Rome sous le patronage de l'Institut national d'archéologie et d'art de Tunis, Rome 3-5 décembre 1987. École française de Rome, Rome: 425-94.

Di Vita-Evrard, G. 1978-79. Les plus ancien milliaire de Tripolitaine: A. Caecina Severus proconsul d'Afrique. Libya Antiqua 15-16: 9-44.

Di Vita-Evrard, G. 1979. Quatre inscriptions du Djebel Tarhuna: le territoire de Lepcis Magna. Quaderni di archeologia della Libia 10: 67-98.

Di Vita-Evrard, G. 1984. Municipium Flavium Lepcis Magna. Bulletin archéologique du Comité des Travaux Historique et Scientifique. Africa (n.s.) 17B: 197-210.

Di Vita-Evrard, G., Fontana, S., and Musso, L. 1995. Leptis Magna: une tombe exemplaire du Haut-Empire. In P. Trousset (ed.), L’Afrique $d u$ Nord antique et médiévale. Monuments funéraires et institutions autochtones, $\mathrm{VI}^{e}$ colloque international sur l'histoire et l'archéologie de l'Afrique $d u$ Nord (Pau octobre 1993), Éditions du CTHS, Paris: 153-78.

Di Vita-Evrard, G., Fontana, S., Mallegni, F., Munzi, M., and Musso, L. 1996. L'ipogeo dei Flavi a Leptis Magna presso Gasr Gelda. Libya Antiqua (n.s.) 2: 85-133.
Dilke, O. A. W. 1971. The Roman Land Surveyors: An Introduction to the Agrimensores. David \& Charles, Newton Abbot.

Filippi, M. R. 1983a. Le procedure: le operazioni preliminari. In Misurare la terra: centuriazione e coloni nel mondo romano. Edizione Panini, Modena: 124-27.

Filippi, M. R. 1983b. Le procedure: la delimitazione dei confini. In Misurare la terra: centuriazione e coloni nel mondo romano. Edizione Panini, Modena: 135-39.

Fontana, S. 1996. Le necropoli di Leptis Magna. Introduzione. Libya Antiqua (n.s.) 2: 79-83.

Francisci, D. 2010. Le sepolture come indicatori di centuriazione. Due casi studio dal Trentino-Alto Adige-Sudtirol (Italia). Agri Centuriati: An International Journal of Landscape Archaeology 7: 283-88.

Francisci, D. 2017. Locus sepulturae. Il valore topografico delle evidenze funerarie in età romana: teoria, metodi e casi di studio dal Trentino-Alto Adigel Südtirol. Edizioni Quasar, Rome.

Gascou, J. 1972. La politique municipale de l'Empire romain en Afrique Proconsulaire de Trajan à Septime Sévère. (Collection de l'École française de Rome 8). École française de Rome, Rome.

Gasperini, L. 1988. Note di epigrafia Lepcitana. In A. Mastino (ed.), L'Africa Romana. (Atti del V convegno di studio. Sassari 11-13 dicembre 1987). Pubblicazioni del Dipartimento di Storia dell'Università degli Studi di Sassari, Sassari: 15366.

Goodchild, R. G. 1948. The Roman roads and milestones of Tripolitania (discoveries and researches in 1947). Reports and Monographs of the Department of Antiquities in Tripolitania 1: 5-31.

Goodchild, R. G. 1949. Recent explorations and discoveries. Reports and Monographs of the Department of Antiquities in Tripolitania 2: 37-41.

Goodchild, R. G. 1951. Roman sites on the Tarhuna Plateau of Tripolitania. Papers of the British School at Rome 19: 43-77.

Goodchild, R. G. 1968. Roman roads of Libya and their milestones. In F. F. Gadallah (ed.), Libya in History: Proceedings of a Historical Conference (16-23 March 1968). University of Libya, Benghazi: 155-71.

Goodchild, R. G., and Ward-Perkins, J. B. 1953. The Roman and Byzantine defences of Lepcis Magna. Papers of the British School at Rome 21: 42-73.

Guidi, G. 1933. La villa del Nilo. Africa Italiana 5.1-2: $1-56$. 
Haynes, D. E. L. 1981. The Antiquities of Tripolitania (4th edition). Department of Antiquities, Tripoli.

Holland, L. A. 1961. Janus and the Bridge: Papers and Monographs of the American Academy in Rome 21. Rome.

Humphrey, J. H., Sear, F. B., and Vickers, M. 1972-73. Aspects of the Circus at Lepcis Magna. Libya Antiqua 9-10: 25-97.

Humphrey, J. H. 1986. Roman Circuses: Arenas for Chariot Racing. Batsford, London.

Jones, G. B. D. 1989. Town and city in Tripolitania: studies in origins and development, 1969-1989. Libyan Studies 20: 91-106.

Keay, S. 2010. Research reports: the Ports Project. Papers of the British School at Rome 78: 330-34.

Kolb, A. 2011. Miliaria: ricerca e metodi. L'identificazione delle pietre miliari. In P. Basso (ed.), I miliari lungo le strade dell'impero (Atti del Convegno, Isola della Scala, 28 novembre 2009). Cierre Edizioni, Verona: 17-28.

Lachmann, K. 1848. Schriften der Römischen Feldmesser (Gromatici veteres ex recensioni Caroli Lachmanni). Georg Reimer, Berlin.

Laing, G. J. 1908. Roman milestones and capita viarum. Transactions and Proceedings of the American Philological Association 39: 15-34.

Le Gall, J. 1975. Les Romains et l'orientation solaire. Mélanges de l'École française de Rome. Antiquité 87.1: 287-320.

Lothringen (Archduke Ludwig Salvator of Austria). 1874. Yacht-reise in den Syrten - 1873. Wörl's Reisebibliothek, Prague.

Lyon, G. (1821). A Narrative of Travels in Northern Africa in the Years 1818, 1819 and 1820. John Murray, London.

Matoug, J. M. 1995. Excavation at the site of the villa of Wadi Zennad (Khoms). Libya Antiqua (n.s.) 1: 155 .

Mattingly, D. J. 1995. Tripolitania. University of Michigan Press, Ann Arbor.

Méhier de Mathuisieulx, H. 1903. Rapport sur une mission scientifique en Tripolitaine. Nouvelles Archives des Missions Scientifiques et Littéraires 10: 245-77.

Méhier de Mathuisieulx, H. 1906. Rapport sur une mission scientifique en Tripolitaine. Nouvelles Archives des Missions Scientifiques et Littéraires 13: 73-102.

Merighi, A. 1940. La Tripolitania antica. Dalle origini all'invasione degli Arabi, vols 1-2. Airoldi Editore, Verbania.

Miller, K. 1916. Itineraria Romana: Römische Reisewege an der Hand der Tabula Peutingeriana. Strecker und Schröder, Stuttgart.
Müller, K. 1855. Geographi Graeci Minores. Tabulae in Geographos Graecos Minores. Editore Ambrosio Firmin Didot, Paris.

Munzi, M. 2004. Circolazione monetaria in contesto rurale: la Tripolitania tardoantica alla luce delle recenti ricognizioni archeologiche lungo l'uadi Taraglat (antico Cinyps). In M. Khanoussi, P. Ruggeri and C. Vismara (eds), L'Africa Romana. A $i$ confini dell'Impero: contatti, scambi, conflitti (Atti del XV convegno di studio. Tozeur 11-15 dicembre 2002). Carocci, Rome: 327-41.

Munzi, M., and Zennati, M. 2004. Una postazione di miliari presso Abu Kammash (Tripolitania). Libyan Studies 35: 123-30.

Munzi, M., and Zocchi, A. 2017. The Lepcitanian territory: cultural heritage in danger in war and peace. Libyan Studies 48: 51-67.

Munzi, M., Felici, F., Cifani, G., Cirelli, E., Gaudiosi, E., Lucarini, G., and Matoug, J. 2004. A topographic research sample in the territory of Lepcis Magna: Sīlīn. Libyan Studies 35: 11-66.

Munzi, M., Felici, F., Sjöström, I., and Zocchi, A. 2014. La Tripolitania rurale tardoantica, medievale e ottomana alla luce delle recenti indagini archeologiche territoriali nella regione di Leptis Magna. Archeologia medievale. Cultura materiale, insediamenti, territorio 41: 215-45.

Munzi, M., Felici, F., Matoug, J., Sjöström, I., and Zocchi, A. 2016. The Lepcitanian landscape across the ages: the survey between Ras el-Mergheb and Ras el-Hammam (2007, 2009, 2013). Libyan Studies 47: 67-116.

Musso, L., and Bianchi, B. (eds). 2012. Lepcis Magna: Hunting Baths, Building, Restoration, Promotion. All'Insegna del Giglio, Florence.

Musso, L., Fontana, S., Mallegni, F., Masturzo, N., Munzi, M., Ricci, G., Severini, F., and Usai, L. 1996. Il suburbio occidentale di Leptis Magna (uadi er-Rsaf): scavo e ricognizione topografica. Libya Antiqua (n.s.) 2: 152-68.

Musso, L., Baldoni, D., Felici, F., Fontana, S., Mallegni, F., Masturzo, N., Munzi, M., Pentiricci, M., Severini, F., and Usai, L. 1997. Missione Archeologica dell'Università Roma Tre a Leptis Magna, 1996. Libya Antiqua (n.s.) 3: 257-94.

Musso, L., Baldoni, D., Bianchi, B., Cilla, M., Di Vita-Evrard, G., Felici, F., Fontana, S., Mallegni, F., Masturzo, N., Munzi, M., and Usai, L. 1998. Missione Archeologica dell'Università Roma Tre a Leptis Magna, 1997. Libya Antiqua (n.s.) 4: 176-218. Musso, L., Baldoni, D., Bianchi, B., Calì, M. G., Davidde, B., Di Vita-Evrard, G., Munzi, M., Petriaggi, R., Pinna Caboni, B., Ponti, G., and Shebani, R. 2010. Missione archeologica 
dell'Università Roma Tre, 1998-2007. Libya Antiqua (n.s.) 5: 49-78.

Muzzioli, M. P. 2001. Sui tempi di insediamento dei coloni nel territorio. In L. Quilici and S. Quilici Gigli (eds), Urbanizzazione delle campagne nell'Italia antica. L'Erma di Bretschneider, Rome: 7-20.

Oates, D. 1953. The Tripolitanian gebel: settlement of the Roman period around Gasr ed-Daun. Papers of the British School at Rome 21: 81-117.

Ouni, K., Peyras, J., and Debaine, F. 1995. Cadastres des cités libres et images satellitaires: l'exemple de Thapsus. Dialogues d'histoire ancienne 21.2: 370-79.

Paoletti, M. L. 1983. Continuità della centuriazione: fossi, filari e strade. In Misurare la terra: centuriazione e coloni nel mondo romano. Edizione Panini, Modena: 261-67.

Pucci, S., Pantosti, D., De Martini, P. M., Smedile, A., Munzi, M., Cirelli, E., Pentiricci, M., and Musso, L. 2011. Environment-human relationship in historical times: the balance between urban development and natural forces at Leptis Magna (Libya). Quaternary International 242: 171-84.

Regoli, E. 1983. Centuriazione e strade. In Misurare la terra: centuriazione e coloni nel mondo romano. Edizione Panini, Modena: 106-9.

Reynolds, J. 1955. Inscriptions of Roman Tripolitania: a supplement. Papers of the British School at Rome 23: 124-47.

Roldán Hervás, J. M. 1966. Sobre los Acusativos con 'ad' en el Itinerario de Antonino. Zephyrus: Revista de prehistoria y arqueología 17: 109-19.

Romanelli, P. 1925. Leptis Magna. Società Editrice d'arte illustrata, Rome.

Romanelli, P. 1970. Topografia e archeologia dell'Africa Romana. In Enciclopedia Classica, sez. III, vol. X, VII. Società Editrice Internazionale, Turin.

Rosada, G. 2010. Arte (mestiere?) dell'agrimensor. Histria Antiqua. Casopis Meðunarodnog Istraživačkog Centra za Archeologiju. Journal of the International Research Centre for Archaeology 19: $125-52$.

Salama, P. 1951a. Les Voies romaines de l'Afrique $d u$ Nord. Imprimiere officielle, Algiers.

Salama, P. 1951b. Les bornes milliaires de Djemila Cuicul et leur entérêt por l'histoire de la ville. Revue Africaine 95: 213-72.
Salama, P. 1987. Bornes milliaires d'Afrique Proconsulaire. Un panorama historique $d u$ Bas Empire Romain (Collection de l'École française de Rome 101). École française de Rome, Rome.

Salza Prina Ricotti, E. 1970-71. Le ville marittime di Silin (Leptis Magna). Rendiconti: Atti della pontificia accademia romana $d i$ archeologia 43: 135-63.

Sena Chiesa, G. 1997. Monumenti sepolcrali nella Transpadana centrale. Antichità Altoadriatiche 43: 275-312.

Stroppa, F. 1912. Lebda (Leptis Magna) nel maggio 1912. Tipografia Gallardi e Ugo, Vercelli.

Talbert, R. G. A. (ed.). 2000. Barrington Atlas of the Greek and Roman World. Princeton University Press, Princeton, NJ, and Oxford.

Tantillo, I., and Bigi, F. (eds). 2010. Leptis Magna. Una città e le sue iscrizioni in epoca tardoromana. Edizioni dell'Università degli studi di Cassino, Cassino.

Tozzi, P. 1974. Saggi di topografia storica. La Nuova Italia, Florence.

Vergara Caffarelli, E. 1954. Notiziario. Attività del Dipartimento delle Antichità dal Luglio 1951 al Settembre 1953 in Tripolitania. Quaderni di archeologia della Libia 3: 117-18.

Vita-Finzi, C. 1969. The Mediterranean Valleys: Geological Changes in Historical Times. Cambridge University Press, Cambridge.

Ward-Perkins, J. B., and Toynbee, J. M. C. 1949. The Hunting Baths at Lepcis Magna. Archaeologia 93: 165-95.

Willi, A. 2014. Land division and water management in the west of the Roman Empire. In A. Kolb (ed.), Infrastruktur und Herrschaftsorganisation im Imperium Romanum: Herrschaftsstrukturen und Herrschaftspraxis III (Akten der Tagung in Zürich 19.-20.10.2012). Oldenbourg, Berlin: 137-57.

Wilson, A. I. 1999. Deliveries extra urbem: aqueducts and the countryside. Journal of Roman Archaeology 12: 314-31.

Wilson, A. I. 2008. Hydraulic engineering and water supply. In J. P. Oleson (ed.), The Oxford Handbook of Engineering and Technology in the Classical World. Oxford University Press, Oxford and New York: 285-318. 